University of Nebraska - Lincoln

DigitalCommons@University of Nebraska - Lincoln

Biological Systems Engineering: Papers and

Publications

Biological Systems Engineering

2013

\title{
Assessing climate change impacts on water balance, runoff, and water quality at the field scale for four locations in the heartland
}

\author{
Michael W. Van Liew \\ University of Nebraska-Lincoln, vanliew@windstream.net \\ Song Feng \\ University of Arkansas, songfeng@uark.edu \\ T. B. Pathak \\ University of Nebraska-Lincoln, tpathak2@unl.edu
}

Follow this and additional works at: https://digitalcommons.unl.edu/biosysengfacpub

Part of the Bioresource and Agricultural Engineering Commons, Environmental Engineering Commons, and the Other Civil and Environmental Engineering Commons

Van Liew, Michael W.; Feng, Song; and Pathak, T. B., "Assessing climate change impacts on water balance, runoff, and water quality at the field scale for four locations in the heartland" (2013). Biological Systems Engineering: Papers and Publications. 409.

https://digitalcommons.unl.edu/biosysengfacpub/409

This Article is brought to you for free and open access by the Biological Systems Engineering at DigitalCommons@University of Nebraska - Lincoln. It has been accepted for inclusion in Biological Systems Engineering: Papers and Publications by an authorized administrator of DigitalCommons@University of Nebraska Lincoln. 


\title{
ASSESSING CLIMATE CHANGE IMPACTS ON WATER BALANCE, RUNOFF, AND WATER QUALITY AT THE FIELD SCALE FOR FOUR LOCATIONS IN THE HEARTLAND
}

\author{
M. W. Van Liew, S. Feng, T. B. Pathak
}

\begin{abstract}
This study employed the Soil and Water Assessment Tool (SWAT) to evaluate the impacts of projected future climate change scenarios on water balance, runoff, sediment, total nitrogen $(N)$, and total phosphorus $(P)$ at the field scale for four locations in the Heartland region: Sioux City (Iowa) and Columbus, Mullen, and Harrison (Nebraska). A conventional two-year corn-soybean rotation was assumed to be grown on each field. All fields were simulated identically in terms of topographic and cover/land management conditions. Model inputs for the fields differed in only three ways: the forcing conditions for existing and future climatic scenarios (SRES A2, A1B, and B1), soil and aquifer properties, and calibrated parameters at each location. Model simulations indicate that for the Columbus and Sioux City sites, where current average annual precipitation is about 740 and $650 \mathrm{~mm}$, respectively, substantial increases in runoff and pollutant loadings from a corn-soybean crop rotation are projected to occur during the spring under future climate scenarios in comparison to existing conditions. At the Sioux City site, for example, increases in runoff of $213 \%, 124 \%$, and $128 \%$ during the month of May are projected for the A2, A1B, and B1 scenarios, respectively, in comparison to the baseline condition. Very large increases in attendant sediment and nutrient losses are also projected for that month at the Sioux City site. Considerably greater attention in coming years will therefore likely be necessary to devise best management practices and adaptation strategies that can be effectively employed to conserve soil and water resources and to protect streams and receiving waters from the harmful effects of higher pollutant loadings. At the Harrison site, where average annual precipitation is less than $450 \mathrm{~mm}$, increases in average annual evapotranspiration of 29, 31, and $46 \mathrm{~mm}$ under the $A 2, A 1 B$, and B1 future climate scenarios are projected to occur for a corn-soybean crop. Relative to the baseline at this site, water requirements are projected to be 37,39, and $32 \mathrm{~mm}$ greater, respectively, for the peak irrigation month of July under the A2, A1B, and B1 scenarios. For regions in western Nebraska with similar or lesser precipitation levels, these anticipated changes could exacerbate already existing challenges for agricultural producers who primarily rely upon groundwater for irrigation. SWAT was employed to simulate the impact of four best management practices (BMPs) on changes in sediment, total $N$, and total $P$ under the baseline and future climate change scenarios for each site. These four treatments included conversion of the corn-soybean rotation to pasture, switchgrass, and no-till, and implementation of a $10 \mathrm{~m}$ wide edge-of-field buffer strip. At all four sites, the pasture and switchgrass BMPs reduced sediment and total P yields by $97 \%$ to $99 \%$ in comparison to the corn-soybean cover crop. Each of the BMP treatments employed in this study appears to hold promise in providing potential reductions in sediment and nutrients for the two eastern field sites. However, further analyses are needed to not only assess the impact of other types of BMPs, but their cost effectiveness and sustainability as well. Model simulations suggest that, for the Harrison site, moderate decreases in sediment, total $N$, and total $P$ are projected to occur for the no-till BMP and modest decreases for the $10 \mathrm{~m}$ buffer strip BMP. Model simulations also suggest that, of the four BMP types, only the pasture and switchgrass treatments appear to provide appreciable reductions in sediment and nutrients at the Mullen site.
\end{abstract}

Keywords. Model Calibration, Hydrology, Water Quality, Climate Change, SWAT.

Submitted for review in March 2011 as manuscript number SW 9134; approved for publication by the Soil \& Water Division of ASABE in May 2013.

The authors are Michael W. Van Liew, ASABE Member, Research Specialist, Department of Biological Systems Engineering, University of Nebraska, Lincoln, Nebraska, Song Feng, Assistant Professor, Department of Geosciences, University of Arkansas, Fayetteville, Arkansas (formerly Research Assistant Professor, School of Natural Resources, University of Nebraska, Lincoln, Nebraska), and Tapan B. Pathak, Extension Educator, School of Natural Resources, University of Nebraska, Lincoln, Nebraska. Corresponding author: Michael W. Van Liew, 229 L.W. Chase Hall, Lincoln, NE 68583-0726; phone: 402-4720839; email: mvanliew2@unl.edu.

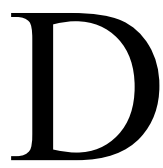

uring the past few decades, the impact of climate change has led to increases in average temperatures throughout the Heartland region of Iowa, Nebraska, Kansas, and Missouri, with the largest increases occurring in the winter months. Temperatures in this region of the U.S. are expected to continue to increase over this century, with larger changes expected under scenarios of higher heat-trapping emissions as compared to lower emissions (www.globalchange.gov/ usimpacts). By the end of the 21 st century, northeastern areas of the Heartland are expected to experience much wetter springs, whereas southwestern areas are projected to be drier. Projected changes also include more frequent 
extreme events, such as droughts, heat waves, and heavy rainfall.

Climate change has caused subtle to moderate changes in hydrologic and water quality conditions and is likely to continue causing changes in the future at a range of spatial and temporal scales throughout the Heartland. These changes have brought about impacts to streamflow frequency, peak discharge, flow volume, and baseflow in addition to changes in sediment, nutrient, pesticide, and other pollutant loadings. Donner et al. (2002) coupled the Integrated Biosphere Simulator (IBIS) and Hydrological Routing Algorithm (HYDRA) models to simulate runoff and nitrate losses from the Mississippi River basin during the 1955 to 1994 period. They reported that about onefourth of the increase in nitrate losses was attributed to increases in runoff as a result of increased precipitation across the basin. In addition to increases in precipitation that have led to subsequent increases in stream discharge (Goolsby et al., 1999), Tomer and Schilling (2009) pointed out that decreases in evaporative demand may also be the cause of increases in streamflow in the Upper Midwest. A number of factors, such as nonlinear relationships, multiple causation, and lag effects, complicate our understanding of the cause-and-effect relationships between climate change and hydrologic response.

Understanding these cause-and-effect relationships is further complicated by our difficulty in distinguishing the effects of land use changes from concurrent climate variability (Lioubimtseva et al., 2005; Tollan, 2002). Schilling et al. (2008), for example, employed the Soil and Water Assessment Tool (SWAT) on the Raccoon River watershed in Iowa and showed that changes in agricultural land from mixed perennial and annual systems to annual row crops during the past century have led to increases in streamflow for the watershed. Using the IBIS model, Twine et al. (2004) reported that Mississippi River basin runoff increased during the latter portion of the 20th century as a result of changes from forest to current cover, particularly in the eastern, humid part of the basin. Hanratty and Stefan (1998) performed model simulations with SWAT to assess the impacts of future climate change on streamflow and water quality for an agricultural watershed in Minnesota. Based on their modeling assumptions and procedures used for calibrating SWAT, they found that changes in land use, land cover, and management practices were likely to have a greater impact on the water quality response of the watershed in comparison to the impact due to future climate change.

In addition to the aforementioned complexities, our understanding of the impacts of climate change on hydrology and the attendant fate and transport of pollutant constituents is confounded by a number of uncertainties. Considerable uncertainty exists, for example, in determining how future changes in climatic variables such as air temperature, precipitation, and greenhouse gas emissions will impact hydrologic responses at field, watershed, or basin scales. Little is known as to what extent changes in the magnitude and frequency of precipitation events will affect storm runoff and the detachment and transport of pollutants from the landscape, which in turn impact downstream receiving waters such as streams and lakes. Uncertainties related to the incidence of prolonged drought could have dire effects on water availability for urban, industrial, or agricultural needs. The effectiveness of implementing best management practices (BMPs) to reduce pollutant load reduction is also not well understood under future climate change conditions. With changes that occur in climate, excessive losses of pollutants within a watershed may become so great that current BMPs may no longer exhibit the capacity to treat these conditions (Wilby et al., 2006).

A need clearly exists to accurately assess the impact of future climate change on runoff and transport of water quality constituents for cropping and management systems on a regional basis. This in turn may lead to a better understanding of how changes in future water resources will affect regional livelihood, environment, wildlife, and human health. A need also exists to determine how future climate change will impact the effectiveness of BMPs on water quantity and water quality at specific sites. Because of the inherent complexity in understanding the impacts of climate change on hydrologic and water quality processes that occur across the landscape, increasingly sophisticated modeling approaches are needed to adequately quantify the spatial and temporal variations in runoff and pollutant fate and transport.

With a trend toward the implementation of numeric water quality standards throughout the U.S., more sophisticated methods are being developed to quantify pollutant losses from agricultural landscapes. Over the past decade, simulation models such as SWAT and the Agricultural Policy Environmental eXtender (APEX) have been used increasingly to identify management strategies that meet numeric water quality standards (Storm et al., 2006). These tools simulate landscape processes that govern sediment, nutrient, or pesticide fate and transport for a variety of land management, soils, and climatic conditions. They can also evaluate BMP alternatives that can be implemented to minimize the impact of pollutant losses on the environment.

Many studies may be found in the literature describing how SWAT has been employed to determine the impacts of climate change on streamflow and water quality. Eckhardt and Ulbrich (2003) coupled output from global circulation models (GCMs) with SWAT to assess the impact of future climate change scenarios on streamflow and groundwater recharge for the Dill watershed in Germany. Githui et al. (2009) performed a similar study with SWAT to assess potential climate changes on a watershed in the Lake Victoria basin in Kenya. Ficklin et al. (2009) used SWAT to simulate potential hydrologic responses to future climate change in the San Joaquin watershed in central California. Jha et al. (2004) showed anticipated increases in surface runoff and groundwater recharge in the Upper Mississippi River basin under future climate change scenarios based on evaluations using a regional climate model (RCM) that was coupled with SWAT. Woznicki et al. (2011) and Van Liew et al. (2012) reported expected increases in streamflow, sediment, and nutrients for future climatic conditions on watersheds in eastern Nebraska, based on simulations with 
SWAT. Both of these studies also compared BMP responses under existing and future climate change scenarios.

Recently, White et al. (2010) reported the development of an assessment tool capable of simulating runoff, sediment, and phosphorus losses from agricultural fields. Their field tool, referred to as PPM Plus, provides estimates of sediment, runoff, and phosphorus that are delivered to a stream by using SWAT's subbasin-scale components. PPM Plus represents a powerful modeling approach that can be used to not only predict pollutant loadings from agricultural landscapes, but also the impact of BMPs on load reductions. It also holds considerable promise in helping agricultural producers evaluate the impacts of future climate changes on runoff and pollutant loadings and the implications of BMP treatments for various topographic, soils, and land management conditions.

In order to better understand the impacts of future climate scenarios and BMPs on runoff and pollutant losses from the landscape, we employed the hydrologic response unit (HRU) component in SWAT to conduct a hypothetical investigation at four locations in the Heartland region (fig. 1). SWAT was used to simulate the landscape response of runoff, sediment, total nitrogen $(\mathrm{N})$, and total phosphorus (P) from four 64.8 ha fields, assumed to be located near Sioux City, Iowa, and Columbus, Mullen, and Harrison, Nebraska. The first objective of this study was to compare the spatial and temporal variations in hydrologic and water quality response at the four sites for a conventionally tilled corn-soybean rotation under an

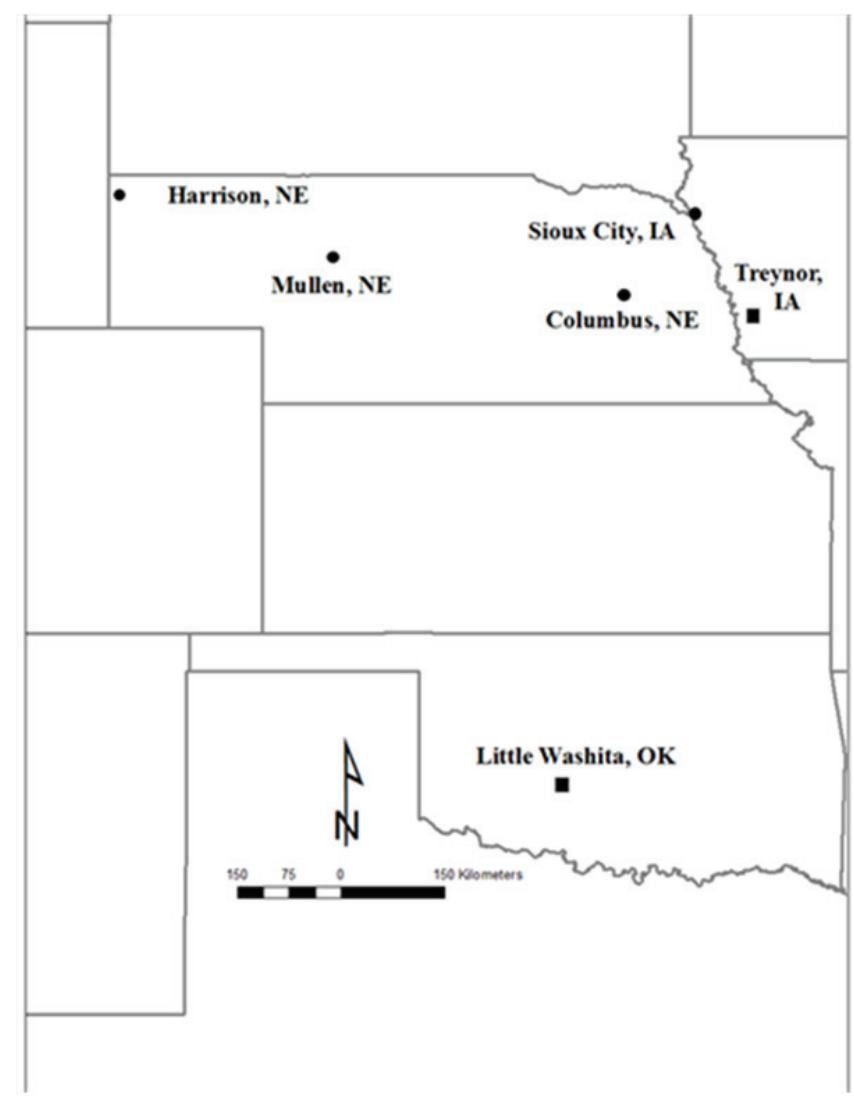

Figure 1. Location of the calibration, validation, and hypothetical field sites. existing climate scenario and three future climate change scenarios. The second objective was to assess the impact of four BMP treatments on reductions in sediment and nutrients for the existing and future climate change scenarios. These BMP treatments included conversion of cropland to pasture, conversion to switchgrass, a $10 \mathrm{~m}$ filter strip, and a no-till corn-soybean rotation.

\section{METHODOLOGY \\ SWAT MODEL ADAPTATION}

SWAT is a distributed parameter model that was originally developed by the USDA Agricultural Research Service (ARS) to predict the impact of land management practices on water, sediment, and agricultural chemical yields in large ungauged basins (Arnold et al., 1998). Model simulations performed in SWAT are computed on a daily time step. Hydrologic processes simulated on the landscape include evapotranspiration, snow accumulation and melt, rainfall runoff partitioning, and lateral and groundwater flow (Neitsch et al., 2002).

The model partitions a watershed into a number of subbasins. Each subbasin delineated within the model is simulated as a homogeneous area in terms of climatic conditions, but with additional subdivisions within each subbasin to represent various soils and land use types. Each of these subdivisions is referred to as a HRU and is assumed to be spatially uniform in terms of soils, land use, topographic and climatic data.

On the landscape, erosion and sediment yield are estimated for each HRU in SWAT using the Modified Universal Soil Loss Equation (MUSLE; Williams, 1975), an enhancement of the USLE. SWAT comprehensively models the transfers and internal cycling of the major forms of nitrogen and phosphorus. The model monitors two pools of inorganic and three pools of organic forms of nitrogen. SWAT also monitors three pools of inorganic and three pools of organic forms of phosphorus.

SWAT 2009 was the version of the model that was selected for this study. The USDA Soil Conservation Service (SCS) runoff curve number (CN2) was used to estimate surface runoff from daily precipitation (USDASCS, 1986). Evapotranspiration was computed using the Penman-Monteith method (Monteith, 1965). Crop management schedules and commercial fertilizer application rates were input into the model for the cornsoybean rotation based on professional judgment and estimates by the USDA-NRCS (table 1). Planting and harvest dates for corn and soybeans for the future climate change scenarios were assumed to be the same as those for the existing climate scenario. The auto-irrigation routine in SWAT was employed for irrigating the corn-soybean and switchgrass fields based on a plant cover water stress factor.

In SWAT 2009, the impact of elevated levels of $\mathrm{CO}_{2}$ on plant productivity and water requirements are considered in two ways: (1) an increase in radiation use efficiency, and (2) a reduction in stomatal conductance. For the first condition, radiation use efficiency is assumed to vary as: 
Table 1. Conventional operations for the corn-soybean rotation.

\begin{tabular}{cccc}
\hline $\begin{array}{c}\text { Year } \\
\text { (and Crop) }\end{array}$ & Date & Operation & $\begin{array}{c}\text { Application } \\
\text { Rate } \\
\left(\mathrm{kg} \mathrm{ha}^{-1}\right)\end{array}$ \\
\hline $\begin{array}{c}\text { Year 1 } \\
\text { (soybeans) }\end{array}$ & 5 April & Auto-irrigation & - \\
& 10 April & Tandem disk tillage & - \\
& 30 April & Atrazine application & 1 \\
& 1 May & 18-46-00 fertilizer & 175 \\
& 15 May & Plant soybeans & - \\
& 30 Sept. & Harvest and kill & - \\
Year 2 & 25 Oct. & Anh-NH3 fertilizer & 170 \\
(corn) & 10 April & Auto-irrigation & - \\
& 30 April & Tandem disk tillage & - \\
& Atrazine application & 1 \\
& 30 May & Plant corn & - \\
& & Harvest and kill & - \\
\hline
\end{tabular}

$$
\mathrm{RUE}=100 \mathrm{CO}_{2} /\left[\mathrm{CO}_{2}+\exp \left(r_{1}-r_{2} \mathrm{CO}_{2}\right)\right]
$$

where RUE is the radiation use efficiency of the plant that reflects elevated $\mathrm{CO}_{2}$ effects, and $r_{1}$ and $r_{2}$ are shape coefficients that are a function of the ambient and elevated values of $\mathrm{CO}_{2}$ and the ambient (BIO_E) and elevated (BIOEHI) values of radiation use efficiency. For all simulated cover crops used in this study, default values of $\mathrm{BIO} \mathrm{E}$ and BIOEHI were assumed to be valid for both the baseline and future climate change scenarios. Under the second condition, leaf conductance is assumed to vary as:

$$
g_{\mathrm{CO} 2}=g\left[1.4-0.4\left(\mathrm{CO}_{2} / 330\right)\right]
$$

where $g_{\mathrm{CO} 2}$ is the leaf conductance modified to reflect $\mathrm{CO}_{2}$ effects, $g$ is the conductance without $\mathrm{CO}_{2}$ effects, $\mathrm{CO}_{2}$ is the concentration of carbon dioxide in the atmosphere, and 330 is the assumed present-day $\mathrm{CO}_{2}$ concentration. The inverse relationship shown in equation 2 is based on a study by Morison (1987), who found that for $\mathrm{CO}_{2}$ concentrations between 330 and $660 \mathrm{ppmv}$ (parts per million by volume), a doubling of $\mathrm{CO}_{2}$ concentration led to a $40 \%$ reduction in leaf conductance for arable land. Ficklin et al. (2009) noted that the assumed inverse relationship in SWAT given by equation 2 may overestimate stomatal conductance for elevated values of $\mathrm{CO}_{2}$ for forest, pasture, and range land, based on work by Wand et al. (1999), Pritchard et al. (1999), and Field et al. (1995). Ficklin et al. (2009) also noted that SWAT does not account for an increase in the leaf area index (LAI) for plant growth simulated in the model under elevated $\mathrm{CO}_{2}$ concentrations.

To overcome these two limitations, Eckhardt and Ulbrich (2003) modified the source code for SWAT and tabulated suggested values of stomatal conductance and LAI for a range of land cover types. Data from their investigation were used to adjust stomatal conductance and LAI for elevated values of $\mathrm{CO}_{2}$ employed in this study. For a doubling of $\mathrm{CO}_{2}$ concentrations between 330 and 660 ppmv: (1) a $40 \%$ reduction in stomatal conductance was assumed for the corn-soybean rotation and a $25 \%$ reduction was assumed for the switchgrass and pasture BMP treatments, and (2) a $37 \%$ increase in LAI was assumed for the crop rotation and a $20 \%$ increase was assumed for the two BMP treatments. Hence, equation 2 was assumed to be valid for estimating the stomatal conductance for corn and soybeans for elevated values of $\mathrm{CO}_{2}$ under future climatic conditions, while values of $\mathrm{CO}_{2}$ for the switchgrass and pasture BMP treatments were adjusted proportionally downward in the SWAT subbasin file to mimic the stomatal conductance response of these two cover types under future climatic conditions. Values of LAI for the respective crop and BMP cover conditions were adjusted upward in SWAT's crop file for the three future climate scenarios.

\section{TEST FIELDS}

Model simulations were conducted with SWAT on four hypothetical 64.8 ha fields located near Sioux City, Iowa, and Columbus, Mullen, and Harrison, Nebraska (fig. 1). The two eastern sites (Sioux City and Columbus) are located in the semi-humid region of the Central Great Plains, while the two western sites (Mullen and Harrison) are located in the semi-arid region. According Karl et al. (2009), these four sites are situated along a steep gradient in terms of projected temperature and precipitation responses to climate change. Therefore, an evaluation of the impacts of future climate change on water quantity and quality at these four sites may lead to better preparation and adaptive strategies to manage and alleviate the impacts of climate change across the region. All four fields were simulated identically as HRUs in SWAT in terms of topographic and cover/land management conditions; soil and aquifer properties were varied by location. Simulations were performed for a two-year irrigated corn-soybean rotation. Four additional simulations were run at each site as BMP treatments: (1) two-year no-till irrigated cornsoybean rotation, (2) two-year irrigated corn-soybean rotation with a $10 \mathrm{~m}$ edge-of-field buffer strip, (3) continuous pasture, and (4) continuous irrigated switchgrass with spring fertilization. Each homogeneous field was assumed to have a slope length of $61 \mathrm{~m}$ and steepness of $4 \%$. Both the Sioux City and Columbus sites were assumed to be comprised of silty-clay soil ( $31 \%$ clay, $62 \%$ silt, $7 \%$ sand) from the Nora soil series and hydrologic soil group B. The Mullen site was assumed to be a loamy fine sandy soil (6\% clay, $7 \%$ silt, $87 \%$ sand) from the Valentine soil series and hydrologic soil group A, while the Harrison site was assumed to be a loamy very fine sandy soil (10\% clay, $10 \%$ silt, $80 \%$ sand) from the Busher soil series and hydrologic soil group B. Model inputs for the fields differed in only three ways: the forcing conditions for existing and future climatic scenarios, the soil characteristics for each site, and four parameter values in SWAT selected for simulations at each location.

\section{Field Sites For Model CALIBRation AND VALIDATION}

Because of the scarcity of edge-of-field data for calibrating parameters in SWAT for the respective test sites, other data sources were used in this study for model calibration and validation. The USDA-ARS experimental watershed referred to as W2 near Treynor, Iowa, was used to calibrate parameters that govern landscape hydrologic processes in SWAT for the four test locations under the corn-soybean rotation. The W2 site consists of fine silt loam soils that are developed on a deep loessal mantle, with slopes of $2 \%$ to $4 \%$ on the ridges and bottoms and 12 to 
Table 2. Default parameter values and calibrated values for watershed W2 near Treynor, Iowa.

\begin{tabular}{|c|c|c|c|c|}
\hline Category & Parameter & Description & $\begin{array}{c}\text { Default } \\
\text { Value }\end{array}$ & $\begin{array}{l}\text { Calibrated Value } \\
\text { for } \mathrm{W} 2\end{array}$ \\
\hline Basin & SURLAG & Surface runoff lag time & 4 & 0.6 \\
\hline Surface & $\begin{array}{c}\text { ESCO } \\
\text { SOL AWC }\end{array}$ & $\begin{array}{l}\text { Soil evaporation compensation factor } \\
\text { Available soil water capacity }\end{array}$ & $\begin{array}{c}0.95 \\
0 \%\end{array}$ & $\begin{array}{c}0.85 \\
0 \%\end{array}$ \\
\hline Subsurface & $\begin{array}{l}\text { ALPHA_BF } \\
\text { GWQMN } \\
\text { GW_REVAP } \\
\text { REVAPMN } \\
\text { RCHRG_DP } \\
\text { GW DELAY }\end{array}$ & $\begin{array}{c}\text { Baseflow recession constant } \\
\text { Minimum threshold depth for return flow } \\
\text { Groundwater "revap" coefficient } \\
\text { Minimum threshold depth for "revap" } \\
\text { Deep aquifer percolation fraction } \\
\text { Groundwater delay }\end{array}$ & $\begin{array}{c}0.048 \\
0 \\
0.02 \\
1 \\
0.05 \\
31\end{array}$ & $\begin{array}{c}0.009 \\
0 \\
0.02 \\
500 \\
0.05 \\
90\end{array}$ \\
\hline
\end{tabular}

$18 \%$ on the sides (Van Liew and Saxton, 1984). The 33.5 ha catchment is field contoured, with $95 \%$ of the watershed grown in corn and the remaining 5\% consisting of grass waterways. Because of uncertainties associated with the grass waterway on the impact of sediment, nitrogen, and phosphorus deposition, only model parameters in SWAT governing surface and subsurface flow response were calibrated on W2. A manual approach was used to calibrate these nine parameters, which are listed in table 2. Available daily climatic and runoff records at W2 were used for model calibration for a period of record from 1998 to 2000.

Based on results of model simulations performed by Van Liew et al. (2007) on the USDA-ARS Little Washita Experimental Watersheds (LWREW) referred to as 5275, 5273 , and 483 in southwestern Oklahoma, the value of ESCO for this study was assumed to be lower for pasture and switchgrass relative to corn-soybean. For application to these two field treatments, data available from the 43.3 ha USDA-ARS Treynor W3 catchment grown in brome grass were used to calibrate ESCO. Since topographic, climatic, and soil properties are very similar between W2 and W3 (Saxton et al., 1971), all other parameters calibrated on W2 were assumed to be valid for W3, with the exception of the SCS runoff curve number $(\mathrm{CN} 2)$, which was set equal to 61.

The LWREW referred to as 5275 in southwestern Oklahoma was used to validate model parameters calibrated on watershed W2 at Treynor, Iowa. Available daily climate, runoff, sediment, and nutrient records for this 0.61 ha watershed grown in conventional winter wheat were used for model validation. Topography in this region consists of gently to moderately rolling hills on silt loam soils (Van Liew et al., 2007). With the exception of CN2, which was assumed to be equal to 73 , model runoff parameters calibrated from Treynor W2 were used to validate surface runoff responses for LWREW 5275. Default values in SWAT that govern the sediment, total nitrogen, and total phosphorus fate and transport from the landscape were assumed to be valid for estimating the pollutant responses for LWREW 5275. A comparison of land cover types and input values for ESCO and $\mathrm{CN} 2$ for the three USDA-ARS experimental watersheds is presented in table 3 .

\section{Climate InPut Data}

The baseline climatic conditions were developed from National Weather Service observed data for each of the four test sites during 1980 to 2000 . The future climate change scenarios were obtained from the World Climate Research Program's (WCRP) Coupled Model Intercomparison Project phase 3 (CMIP3) multi-model dataset, which were also used in the IPCC AR4 (Meehl et al., 2007). Procedures described by Maurer et al. (2009) were used to downscale monthly temperature and precipitation data using the biascorrection/spatial downscaling method to $0.125^{\circ}$ grids (approx. $10 \mathrm{~km}$ ). Projections from 16 fully coupled climate models covering the contiguous U.S. were employed for statistically downscaling present-day control simulations and future change for the period from 1950 to 2099. A listing of these 16 models is presented by Van Liew et al. (2012). The future climate change projections include three Special Report on Emissions Scenarios (SRES), referred to as A2, A1B, and B1 (Maurer et al., 2009). The A2, A1B, and $\mathrm{B} 1$ climatic conditions represent a range of future economic and energy demand scenarios. The A2 climate scenario is characterized as a world with an emphasis on regionally oriented economic development. Under this scenario, nations are viewed as self-reliant, global population increases continuously, and technological changes and improvements are somewhat fragmented in comparison to other scenarios. The B1 climate scenario represents a more integrated, ecologically friendly world with a population that reaches 9 billion in 2050 and then gradually declines. The $\mathrm{B} 1$ scenario is characterized by the introduction of clean and resource-efficient technologies,

Table 3. Selected parameter values for the soil evaporation compensation factor (ESCO), runoff curve number (CN2), minimum threshold depth for return flow (GWQMN), and deep aquifer recharge (RCHRG_DP) for the calibration, validation, and hypothetical field sites.

\begin{tabular}{|c|c|c|c|c|c|}
\hline Site & Cover Type & ESCO & $\mathrm{CN} 2$ & GWQMN & RCHRG_DP \\
\hline Treynor W2 & Corn & 0.85 & 75 & 0 & 0.01 \\
\hline Treynor W3 & Brome grass & 0.55 & 61 & 0 & 0.01 \\
\hline LWREW 5275 & Winter wheat & 0.85 & 73 & 0 & 0.01 \\
\hline Sioux City and Columbus & Corn-soybean rotation & 0.85 & 77 & 0 & 0.01 \\
\hline Sioux City and Columbus & Pasture and switchgrass & 0.55 & 61 & 0 & 0.01 \\
\hline Mullen & Corn-soybean rotation & 0.85 & 65 & 70 & 0.4 \\
\hline Mullen & Pasture and switchgrass & 0.55 & 39 & 70 & 0.4 \\
\hline Harrison & Corn-soybean rotation & 0.85 & 69 & 900 & 0.4 \\
\hline Harrison & Pasture and switchgrass & 0.55 & 49 & 900 & 0.4 \\
\hline
\end{tabular}


reductions in material intensity, and an emphasis on global solutions to societal and environmental stability. The A1B climate scenario is characterized as a future world with a balanced approach in the use of various energy sources and rapid economic growth (Joos et al., 2001). These three climatic conditions represent a range of future economic and energy demand scenarios, with the A2 and B1 scenarios at the higher and lower ends of the SRES emissions scenarios, respectively, and the A1B representing a moderate increase in emissions (Nakićenović and Swart, 2000).

The future temperature and precipitation were obtained as follows. The statistically downscaled temperature and precipitation during 2040-2059 on the grid point that was closest to Columbus (or one of the other three sites) were chosen first. The temperature and precipitation for the four sites from models with multiple realizations (model runs) were first averaged, and then the ensemble (average) of the 16 model projections was computed by equal weighting of the 16 models for each of the three SRES scenarios. The ensemble of the model projections was used because the average of the outputs from all the available climate models is often the best determinant for simulating mean global and regional climates (Reichler and Kim, 2008; Pierce et al., 2009; Feng et al., 2011). Moreover, monthly values of future climate at Columbus (or the other three sites) were used in the stochastic weather generator, LARS-WG Version 5.0 (Semenov and Stratonovitch, 2010), to generate the weather variables in SWAT at a daily time scale for each site during 2040-2059. Thus, LARS-WG first calculated the empirical statistical mean and distributions of the observed daily weather conditions (e.g., precipitation and temperature) using the observed data for 1980-2000 at Columbus (or the other three sites). Then, the monthly future climate scenarios derived during 2040-2059 were used in LARS-WG to generate daily weather data that were in turn input into SWAT for the future climate at Columbus (or the other three sites), following the same procedures employed by Weiss et al. (2003). To simulate the daily weather conditions for each SRES scenario, 50 years (preceded by a two-year warm-up) of daily meteorological data were generated, using an initial random seed for the weather generator. This 50-year simulation period was assumed to be representative of daily weather conditions expected for the future 2040-2059 period.

The stochastically generated daily data for 2040-2059 were input into SWAT for each of the three future climate scenarios. For the model simulations performed in this study, the concentration of atmospheric carbon dioxide $\left(\mathrm{CO}_{2}\right)$ was assumed to be constant for each climatic condition. $\mathrm{CO}_{2}$ input values to SWAT were assumed to be $350,525,525$, and 475 ppmv for the baseline (1980-2000), A2, A1B, and B1 (2040-2059) scenarios, respectively (www.esrl.noaa.gov/gmd/ccgg/trends/; Woznicki et al., 2011).

\section{RESULTS \\ Model Calibration ANd Field Site PARAMETERIZATION}

Results of the model simulations during the calibration and validation periods were evaluated based on the monthly values of percent bias (PBIAS) and Nash-Sutcliffe coefficient of efficiency (NSE; Nash and Sutcliffe, 1970) (table 4). Based on guidelines suggested by Moriasi et al. (2007), calibrated runoff from the Treynor W2 and W3 field sites was considered satisfactory at the monthly time scale. For the conventional wheat LWREW 5275 field site, model simulations for runoff, sediment, total $\mathrm{N}$, and total $\mathrm{P}$ were considered satisfactory for runoff and good for the three water quality variables. Test results show that SWAT underestimated baseflow for the Treynor W2 field site and overestimated it for LWREW5275; for the latter field site, the model tended to underestimate storm runoff response (fig. 2). SWAT tended to underestimate storm runoff and overestimate baseflow for W3. Although the model generally underestimated total P for LWREW 5275, it did a good job simulating sediment and total $\mathrm{N}$ yield. Validation results obtained on LWREW 5275 indicate that SWAT exhibited an element of robustness in simulating sediment and nutrient losses from that field site, in that no adjustments were made to the parameter values that govern these processes.

Adjustments to four parameters were made in SWAT to account for differences in land cover, soil, and aquifer properties at the four sites. These four parameters included the soil evaporation compensation factor (ESCO), the runoff curve number (CN2), the threshold depth of water in the shallow aquifer required for return flow to occur (GWQMN), and deep aquifer recharge (RCHRG_DP) (table 3). Values selected for $\mathrm{CN} 2$ were based on information published by the USDA-SCS (1986) and engineering judgment. For the Mullen and Harrison sites, which consist of sandy soils that contribute substantially to deep aquifer losses in western Nebraska, available USGS stream gauging data for the Dismal and Niobrara Rivers were used to estimate runoff potential for these two locations. GWQMN was set equal to 70 and 900 for the Mullen and Harrison sites, respectively; RCHRG DP was set equal to 0.4 for both sites. A value of ESCO equal to 0.55 was assumed for the pasture and switchgrass BMPs, based on calibration results from Treynor W3.

For the non-irrigated pasture BMP, average annual evapotranspiration (ET) computed by SWAT for the baseline climate scenario was 729, 651, 472, and $415 \mathrm{~mm}$

Table 4. Monthly runoff, sediment, total nitrogen, and total phosphorus percent bias (PBIAS) and Nash-Sutcliffe coefficient of efficiency (NSE) statistics for the field sites.

\begin{tabular}{|c|c|c|c|c|c|c|c|c|c|c|}
\hline \multirow[b]{2}{*}{ Site } & \multirow{2}{*}{$\begin{array}{c}\text { Time } \\
\text { Series }\end{array}$} & \multirow{2}{*}{$\begin{array}{c}\text { Simulation } \\
\text { Type }\end{array}$} & \multicolumn{2}{|c|}{ Streamflow } & \multicolumn{2}{|c|}{ Sediment } & \multicolumn{2}{|c|}{ Total N } & \multicolumn{2}{|c|}{ Total P } \\
\hline & & & PBIAS & NSE & PBIAS & NSE & PBIAS & NSE & PBIAS & NSE \\
\hline Treynor W2 & 1998-2000 & Calibration & $20.0 \%$ & 0.61 & - & - & - & - & - & - \\
\hline Treynor W3 & $1966-1969$ & Validation & $-5.0 \%$ & 0.53 & - & - & - & - & - & - \\
\hline LWREW 5275 & $1980-1982$ & Validation & $-19.3 \%$ & 0.53 & -15.7 & 0.76 & -15.9 & 0.73 & 36.5 & 0.66 \\
\hline
\end{tabular}



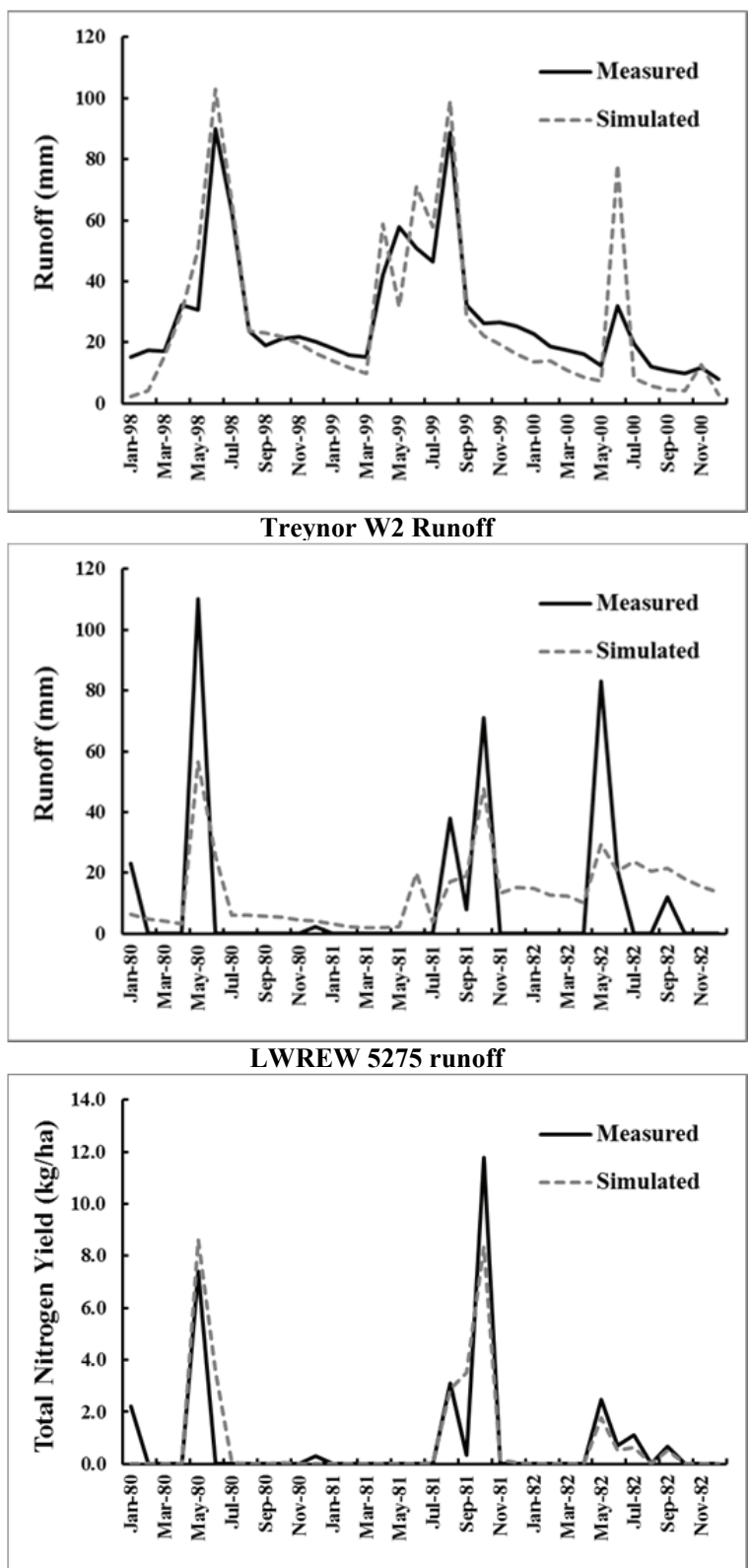

LWREW 5275 nitrogen

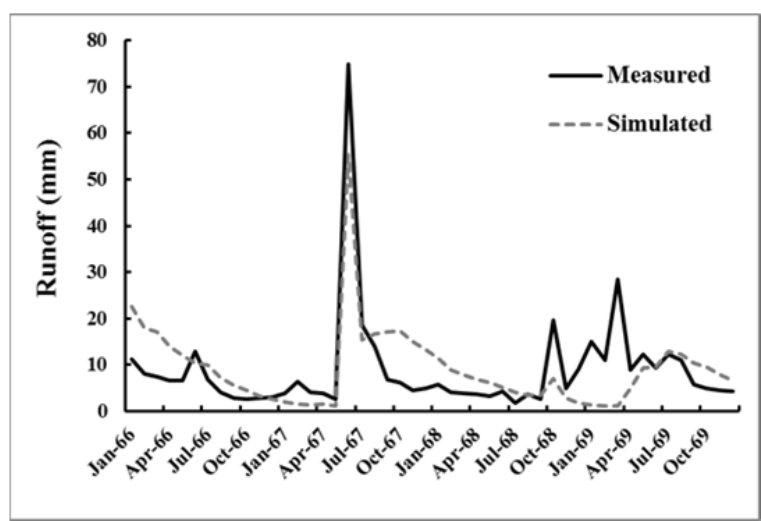

Treynor W3 Runoff
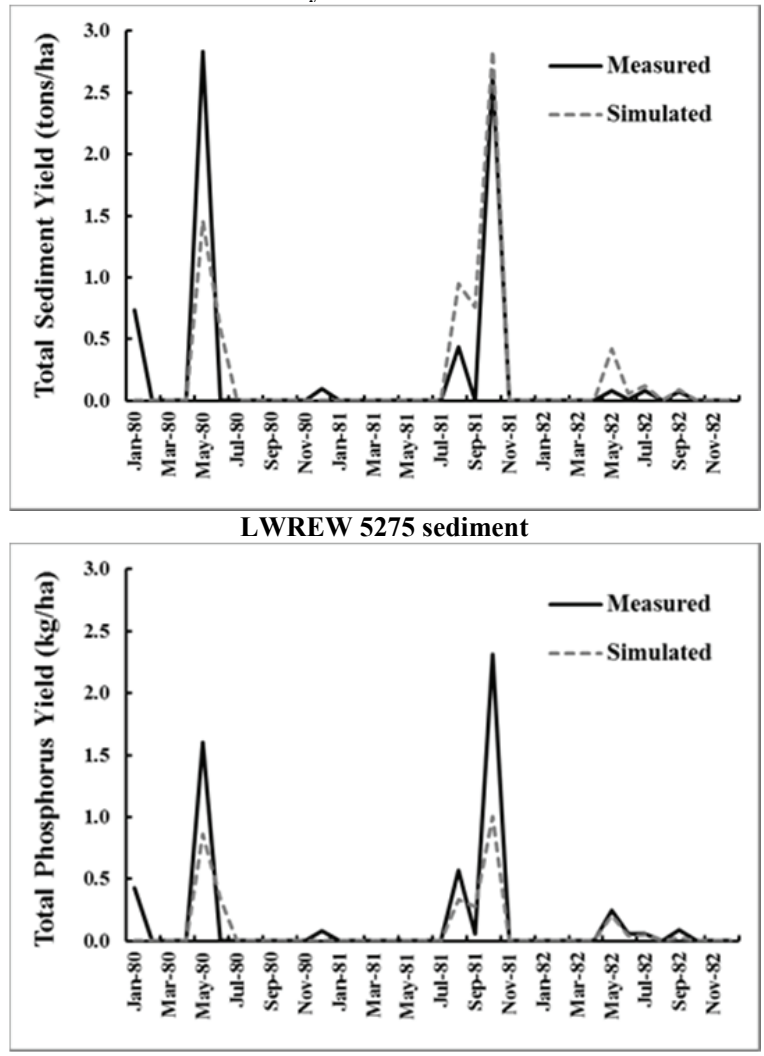

LWREW 5275 phosphorus

Figure 2. Comparison of measured versus simulated runoff and water quality results for the field sites.

for the Columbus, Sioux City, Mullen, and Harrison sites, respectively. These values of ET compare well to those computed with CREMAP across Nebraska from 2000 to 2009 (http://snr.unl.edu/data/water/regionalet.asp). Although not used in this study, cursory testing of average annual ET values simulated by the model for a nonirrigated corn-soybean rotation were found to be 684,627 , 446, and $400 \mathrm{~mm}$ for the Columbus, Sioux City, Mullen, and Harrison sites, respectively. Model simulations of an assumed land cover conversion from pasture to a cornsoybean rotation showed that increases in average annual runoff equal to $45,24,24$, and $14 \mathrm{~mm}$ would be expected to occur for the Columbus, Sioux City, Mullen, and Harrison sites, respectively. These findings are consistent with those reported by Schilling et al. (2008) for a conversion of grasslands to corn production.

\section{Climate Simulations}

At the Sioux City site, average annual maximum and minimum air temperature for the baseline, $\mathrm{A} 2, \mathrm{~A} 1 \mathrm{~B}$, and $\mathrm{B} 1$ scenarios were $15.2^{\circ} \mathrm{C}$ and $3.4^{\circ} \mathrm{C}, 17.4^{\circ} \mathrm{C}$ and $5.6^{\circ} \mathrm{C}$, $17.6^{\circ} \mathrm{C}$ and $5.8^{\circ} \mathrm{C}$, and $17.0^{\circ} \mathrm{C}$ and $5.2^{\circ} \mathrm{C}$, respectively. Compared to the Sioux City site, mean air temperatures were slightly warmer at the Columbus site, slightly cooler at the Mullen site, and moderately cooler at the Harrison site. At the two eastern sites, average annual maximum and minimum air temperatures increased about $2.2^{\circ} \mathrm{C}, 2.4^{\circ} \mathrm{C}$, and $1.8^{\circ} \mathrm{C}$, respectively, for the $\mathrm{A} 2, \mathrm{~A} 1 \mathrm{~B}$, and $\mathrm{B} 1$ scenarios relative to the corresponding baseline temperatures, while at the two western sites, these increases were about $2.0^{\circ} \mathrm{C}$, $2.2^{\circ} \mathrm{C}$, and $1.7^{\circ} \mathrm{C}$.

Figure 3 displays monthly variations in precipitation for the three sites under the baseline and future climate change scenarios. Relative to the baseline, the largest average 

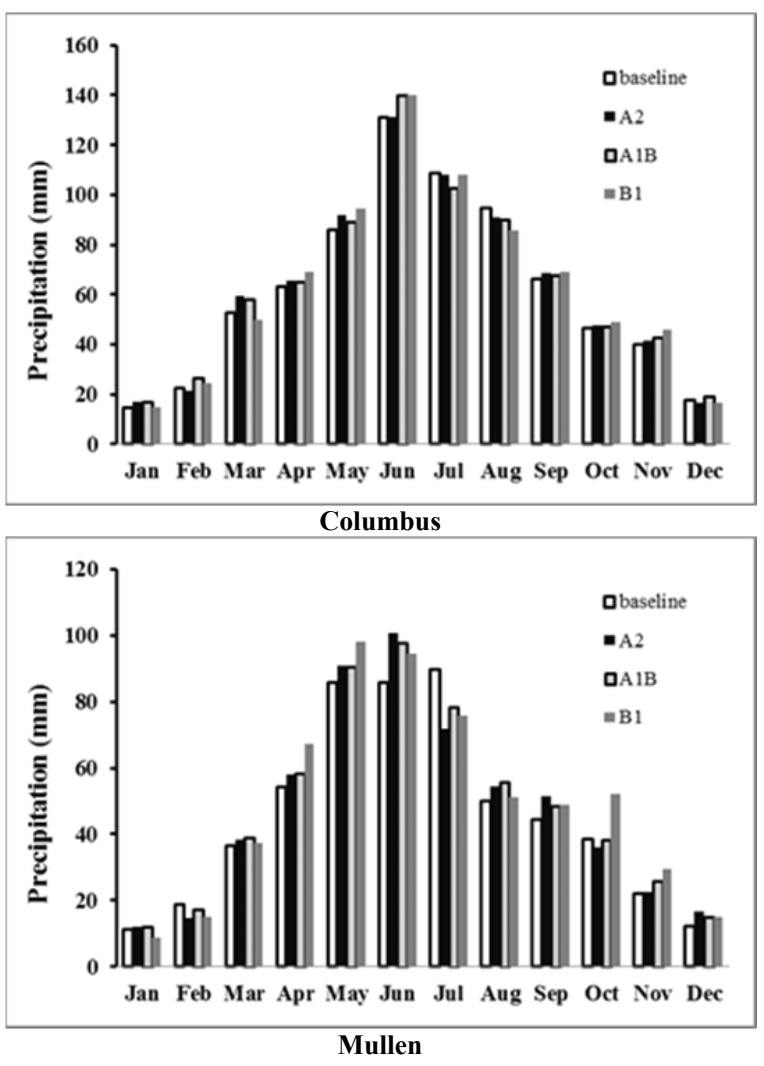
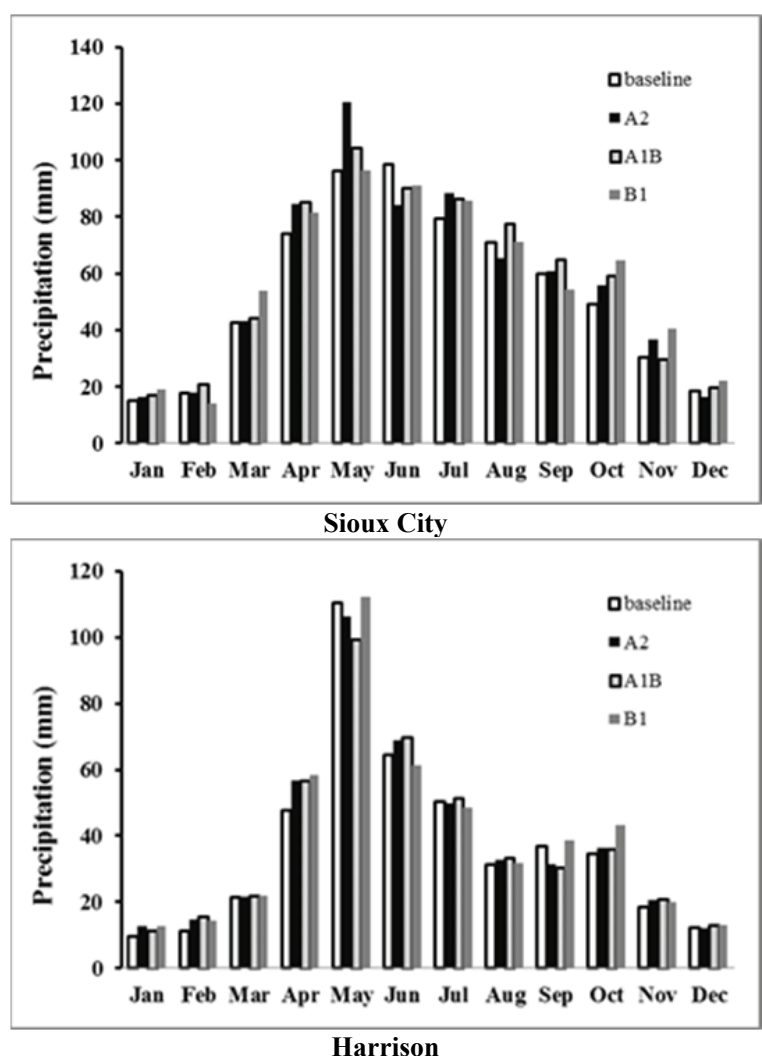

Harrison

Figure 3. Monthly variations in precipitation at the sites for the baseline and three future climate scenarios.

monthly increases in precipitation for the Columbus site are projected to be about $6 \mathrm{~mm}$ (May), $9 \mathrm{~mm}$ (June), and $9 \mathrm{~mm}$ (June) for the A2, A1B, and B1 scenarios, while the largest decreases are projected to be $4 \mathrm{~mm}$ (Aug.), $6 \mathrm{~mm}$ (July), and $9 \mathrm{~mm}$ (Aug.), respectively. Much larger increases of about $24 \mathrm{~mm}$ (May), $11 \mathrm{~mm}$ (April), and $15 \mathrm{~mm}$ (Oct.) are expected to occur at the Sioux City site with moderate decreases of 14, 9, and $8 \mathrm{~mm}$ (June) for the A2, A1B, and B1 scenarios. At the Mullen site, projected increases during the late spring will be about 5, 5, and $12 \mathrm{~mm}$ (May) and 15, 12 , and $9 \mathrm{~mm}$ (June) for the $\mathrm{A} 2, \mathrm{~A} 1 \mathrm{~B}$, and $\mathrm{B} 1$ scenarios, respectively, with the largest decreases of 18, 11, and $14 \mathrm{~mm}$ occurring during the month of July. For Harrison, the largest projected increases in precipitation of 9,9 , and $11 \mathrm{~mm}$ will occur in April, while the largest projected decreases will amount to about $5 \mathrm{~mm}$ (Sept.), $11 \mathrm{~mm}$ (May), and $3 \mathrm{~mm}$ (June) under the $\mathrm{A} 2, \mathrm{~A} 1 \mathrm{~B}$, and $\mathrm{B} 1$ scenarios, respectively.

A comparison of means, standard deviations, and coefficients of variation (CV) for monthly simulated precipitation for the four sites under the baseline and three future climate scenarios is presented in table 5. Also shown in the table is the peak (maximum) monthly precipitation amount simulated for each run. Based on the means and standard deviations reported in table 5, the simulations performed in this study suggest that monthly variability in

Table 5. Comparison of the peak monthly precipitation amount and precipitation statistics for the four sites under the baseline and three future climate change scenarios.

\begin{tabular}{|c|c|c|c|c|c|}
\hline Site & $\begin{array}{c}\text { Precipitation } \\
\text { Variable }^{[\mathrm{a}]}\end{array}$ & $\begin{array}{l}\text { Base } \\
(\mathrm{mm})\end{array}$ & $\begin{array}{c}\mathrm{A} 2 \\
(\mathrm{~mm})\end{array}$ & $\begin{array}{l}\text { A1B } \\
(\mathrm{mm})\end{array}$ & $\begin{array}{c}\mathrm{B} 1 \\
(\mathrm{~mm})\end{array}$ \\
\hline \multirow[t]{4}{*}{ Columbus } & Peak monthly precipitation & 361.4 & 346.6 & 342.2 & 328.2 \\
\hline & Mean monthly precipitation & 61.9 & 63.3 & 63.5 & 63.9 \\
\hline & Standard deviation & 56.6 & 56.8 & 56.9 & 57.2 \\
\hline & Coefficient of variation & 0.91 & 0.90 & 0.90 & 0.90 \\
\hline \multirow[t]{4}{*}{ Sioux City } & Peak monthly precipitation & 232.6 & 327.3 & 266.2 & 269.7 \\
\hline & Mean monthly precipitation & 54.3 & 57.5 & 58.1 & 47.8 \\
\hline & Standard deviation & 43.8 & 50.6 & 48.4 & 46.1 \\
\hline & Coefficient of variation & 0.81 & 0.88 & 0.83 & 0.96 \\
\hline \multirow[t]{4}{*}{ Mullen } & Peak monthly precipitation & 259.5 & 244.3 & 254.5 & 260.1 \\
\hline & Mean monthly precipitation & 45.8 & 47.3 & 47.8 & 49.4 \\
\hline & Standard deviation & 43.9 & 45.3 & 45.5 & 45.4 \\
\hline & Coefficient of variation & 0.96 & 0.96 & 0.95 & 0.92 \\
\hline \multirow[t]{4}{*}{ Harrison } & Peak monthly precipitation & 287.1 & 251.4 & 249.2 & 278.2 \\
\hline & Mean monthly precipitation & 37.3 & 38.7 & 38.2 & 39.6 \\
\hline & Standard deviation & 40.0 & 38.2 & 37.0 & 40.5 \\
\hline & Coefficient of variation & 1.07 & 0.99 & 0.97 & 1.02 \\
\hline
\end{tabular}

[a] Coefficient of variation is dimensionless. 
precipitation under future climate scenarios will not be appreciably different from the baseline condition for the Columbus or Mullen sites. The values in table 5 indicate lesser monthly variability in future projected precipitation at the Harrison site, where the CV for the baseline was computed at 1.07 , compared to $0.99,0.97$, and 1.02 for the $\mathrm{A} 2$, A1B, and B1 scenarios, respectively. For the Sioux City site, greater monthly variability is anticipated under projected future climatic conditions, where the $\mathrm{CV}$ was $0.88,0.83$, and 0.96 for the $\mathrm{A} 2, \mathrm{~A} 1 \mathrm{~B}$, and $\mathrm{B} 1$ scenarios, respectively, compared to 0.81 for the baseline condition.

\section{WATER BUDGET AND CROP YIELDS}

Water budgets were computed for each of the four sites under the baseline and three future climate change scenarios. Hydrologic inputs of precipitation and irrigation water were balanced against abstractions consisting of surface and subsurface flow, deep aquifer recharge, and evapotranspiration (ET) (table 6).

For the corn-soybean scenario under the baseline condition, simulated average annual irrigation amounts were 108, 163, 282, and $246 \mathrm{~mm}$ for the Columbus, Sioux City, Mullen, and Harrison sites, respectively. These rates are similar to the irrigation amounts for corn, which range from $152 \mathrm{~mm}$ in eastern Nebraska to $356 \mathrm{~mm}$ in the west. (www.ianrpubs.unl.edu/pages/publicationD.jsp?publication $\mathrm{Id}=1004 \#$ target2). The model simulations indicate that for the Columbus, Sioux City, and Mullen sites, small decreases in ET are projected to occur under the three future climate change scenarios. For these three sites, decreases are expected to range from $1 \%$ to $5 \%$ with an average of $3 \%$. Small increases in ET of 5\%, 5\%, and 7\% are projected for the Harrison site under the A2, A1B, and B1 scenarios, respectively. For the three future climatic conditions, irrigation water requirements for the cornsoybean rotation were on average greatest at the Harrison site, followed by the Mullen, Sioux City, and Columbus sites. Simulation results suggest that appreciable decreases will occur in irrigation amounts for the Columbus and Sioux City sites, ranging from $28 \%$ to $37 \%$; smaller decreases of $12 \%, 15 \%$, and $9 \%$ are projected for the Mullen site under the A2, A1B, and B1 scenarios, respectively. At the Harrison site, average annual irrigation amounts are expected to increase by $4 \%, 4 \%$, and $11 \%$ under the A2, A1B, and B1 scenarios.

The average corn crop yields for the two-year rotation are also shown in table 6 . The simulation results show that under the baseline condition, corn yield did not differ appreciably among the four sites, ranging from 10.4 tons $\mathrm{ha}^{-1}$ at Mullen to 12.5 tons $\mathrm{ha}^{-1}$ at Sioux City. Baseline values simulated by SWAT are about the same or slightly greater than those reported in recent years by the USDANASS throughout Nebraska for irrigated corn. Modest corn yield reductions under future climate scenarios in comparison to the baseline were observed at the Sioux City site: $8 \%, 10 \%$, and $9 \%$ for the $\mathrm{A} 2, \mathrm{~A} 1 \mathrm{~B}$, and $\mathrm{B} 1$, respectively. Yield reductions of $7 \%$ and $4 \%$ for $A 1 B$ and $\mathrm{B} 1$, respectively, were also simulated at the Columbus site. Reductions of about $6 \%$ were noted at the Mullen site for the three future climate scenarios, while increases of about $5 \%$ were simulated at the Harrison site.

\section{RUNOFF}

Simulation results for runoff and water quality were obtained from the HRU file in SWAT for each respective site and climate scenario. As shown in table 6, widely varying responses in average annual total runoff are projected for the four sites. At the Harrison site, for example, total runoff is expected to decrease by $2 \%$ and $10 \%$ for the $\mathrm{A} 2$ and $\mathrm{A} 1 \mathrm{~B}$ scenarios and increase by $10 \%$ for the B1 scenario, relative to the baseline. Percentage increases in average annual runoff for the A2, A1B, and B1 scenarios relative to the baseline are projected to be $59 \%$, $53 \%$, and $63 \%$, respectively at the Sioux City site. These projected increases are similar to the $50 \%$ increase in runoff reported by Jha et al. (2004), who used SWAT to simulate a

Table 6. Average annual water budget for the four test sites under the baseline and three future climate scenarios.

\begin{tabular}{|c|c|c|c|c|c|c|c|c|c|c|c|c|c|}
\hline \multirow[b]{2}{*}{$\begin{array}{l}\text { Site and } \\
\text { Climate } \\
\text { Scenario }\end{array}$} & \multicolumn{2}{|c|}{ Precipitation } & \multicolumn{2}{|c|}{ Irrigation } & \multicolumn{2}{|c|}{ ET } & \multirow{2}{*}{$\begin{array}{c}\text { Deep } \\
\text { Aquifer } \\
\text { Recharge } \\
(\mathrm{mm})\end{array}$} & \multirow[b]{2}{*}{$\begin{array}{c}\text { Surface } \\
\text { Runoff } \\
(\mathrm{mm})\end{array}$} & \multirow[b]{2}{*}{$\begin{array}{c}\text { Lateral } \\
\text { Flow } \\
(\mathrm{mm})\end{array}$} & \multirow{2}{*}{$\begin{array}{l}\text { Ground } \\
\text { Water } \\
\text { Flow } \\
(\mathrm{mm})\end{array}$} & \multicolumn{2}{|c|}{ Runoff } & \multirow{2}{*}{$\begin{array}{c}\text { Corn } \\
\text { Crop } \\
\text { Yield } \\
\left(\mathrm{t} \mathrm{ha}^{-1}\right)\end{array}$} \\
\hline & $\begin{array}{l}\text { Total } \\
(\mathrm{mm})\end{array}$ & $\begin{array}{c}\text { Change } \\
\text { from } \\
\text { Base }\end{array}$ & $\begin{array}{r}\text { Total } \\
(\mathrm{mm})\end{array}$ & $\begin{array}{c}\text { Change } \\
\text { from } \\
\text { Base }\end{array}$ & $\begin{array}{r}\text { Total } \\
(\mathrm{mm})\end{array}$ & $\begin{array}{c}\text { Change } \\
\text { from } \\
\text { Base }\end{array}$ & & & & & $\begin{array}{l}\text { Total } \\
(\mathrm{mm})\end{array}$ & $\begin{array}{c}\text { Change } \\
\text { from } \\
\text { Base }\end{array}$ & \\
\hline \multicolumn{14}{|l|}{$\overline{\text { Columbus }}$} \\
\hline Base & 743 & - & 108 & - & 784 & - & 0 & 66 & 0 & 1 & 67 & - & 11.4 \\
\hline A2 & 759 & $2 \%$ & 71 & $-34 \%$ & 742 & $-5 \%$ & 0 & 86 & 0 & 2 & 88 & $31 \%$ & 11.8 \\
\hline A1B & 762 & $3 \%$ & 68 & $-37 \%$ & 754 & $-4 \%$ & 0 & 76 & 0 & 0 & 76 & $13 \%$ & 10.6 \\
\hline B1 & 766 & $3 \%$ & 75 & $-31 \%$ & 769 & $-2 \%$ & 0 & 72 & 0 & 0 & 72 & $7 \%$ & 10.9 \\
\hline \multicolumn{14}{|l|}{ Sioux City } \\
\hline Base & 652 & - & 163 & - & 783 & - & 0 & 32 & 0 & 0 & 32 & - & 12.5 \\
\hline $\mathrm{A} 2$ & 690 & $6 \%$ & 118 & $-28 \%$ & 757 & $-3 \%$ & 0 & 50 & 0 & 1 & 51 & $59 \%$ & 11.5 \\
\hline A1B & 697 & $7 \%$ & 108 & $-34 \%$ & 757 & $-3 \%$ & 0 & 47 & 0 & 1 & 48 & $53 \%$ & 11.3 \\
\hline B1 & 694 & $6 \%$ & 102 & $-37 \%$ & 747 & $-5 \%$ & 0 & 48 & 0 & 1 & 49 & $53 \%$ & 11.4 \\
\hline \multicolumn{14}{|l|}{ Mullen } \\
\hline Base & 549 & - & 282 & - & 688 & - & 22 & 26 & 62 & 33 & 121 & - & 10.4 \\
\hline $\mathrm{A} 2$ & 567 & $3 \%$ & 247 & $-12 \%$ & 659 & $-4 \%$ & 26 & 28 & 63 & 38 & 129 & $7 \%$ & 9.8 \\
\hline A1B & 574 & $5 \%$ & 239 & $-15 \%$ & 660 & $-4 \%$ & 25 & 28 & 62 & 38 & 128 & $4 \%$ & 9.8 \\
\hline B1 & 593 & $8 \%$ & 256 & $-9 \%$ & 680 & $-1 \%$ & 29 & 31 & 66 & 43 & 140 & $16 \%$ & 9.7 \\
\hline \multicolumn{14}{|l|}{ Harrison } \\
\hline Base & 448 & - & 246 & - & 626 & - & 26 & 29 & 13 & 0 & 42 & - & 11.3 \\
\hline $\mathrm{A} 2$ & 464 & $4 \%$ & 255 & $4 \%$ & 655 & $5 \%$ & 23 & 28 & 13 & 0 & 41 & $-2 \%$ & 11.9 \\
\hline A1B & 458 & $2 \%$ & 257 & $4 \%$ & 657 & $5 \%$ & 20 & 26 & 12 & 0 & 38 & $-10 \%$ & 11.9 \\
\hline B1 & 475 & $6 \%$ & 272 & $11 \%$ & 672 & $7 \%$ & 29 & 32 & 14 & 0 & 46 & $10 \%$ & 11.8 \\
\hline
\end{tabular}



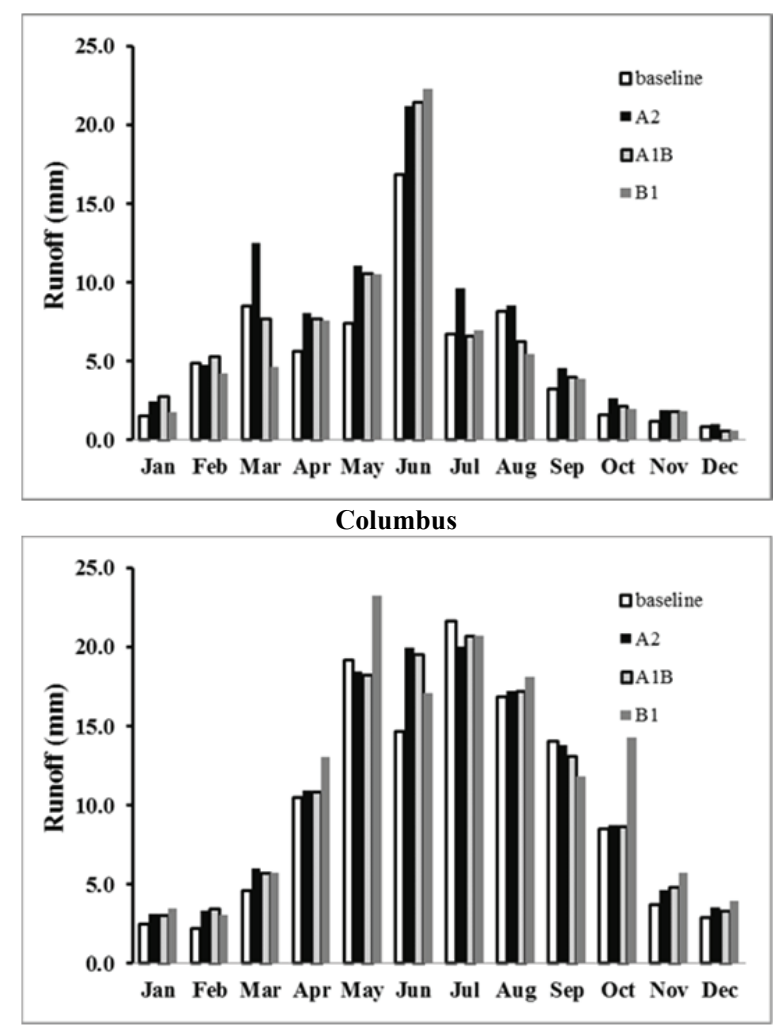

Mullen
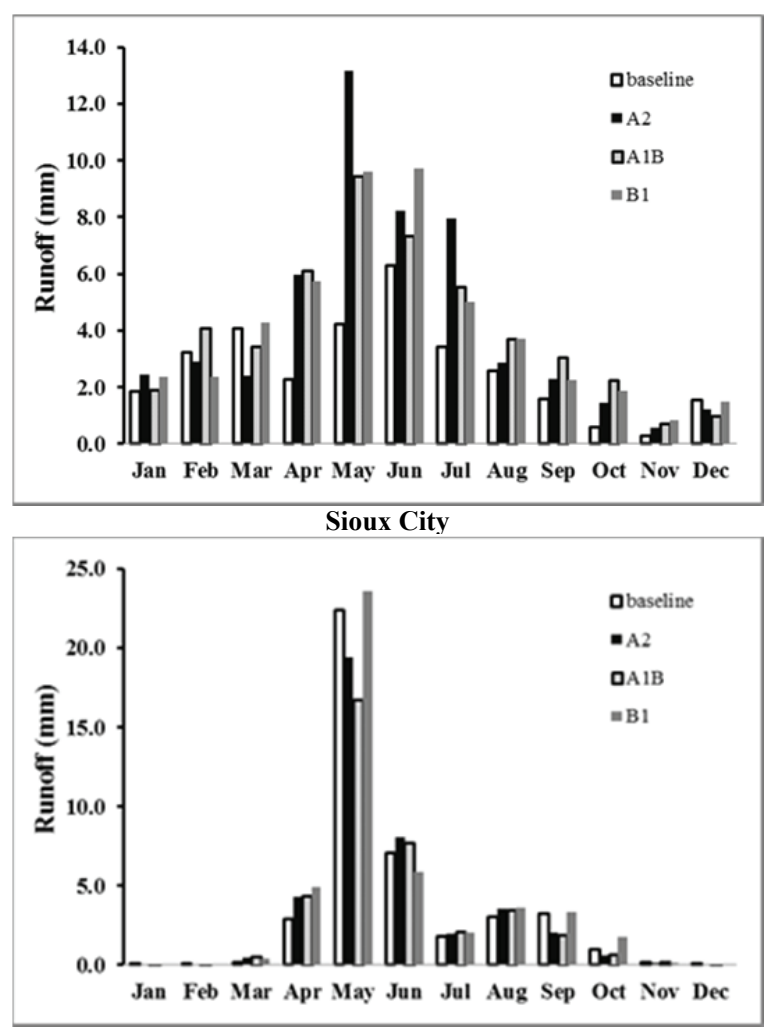

Harrison

Figure 4. Monthly variations in total runoff at the four sites under the baseline and three future climate scenarios.

future climate change scenario from 2040 to 2049 in the Upper Mississippi basin to the east of the Sioux City location.

Monthly variations in runoff at the four sites are displayed in figure 4. At the Sioux City site, large percentage increases in runoff are projected during the months of April, May, October, and November under the three future climate scenarios. For May, these increases for the A2, A1B, and B1 scenarios are $213 \%, 124 \%$, and $128 \%$, respectively, and represent runoff amounts that are about 9 , 5 , and $5 \mathrm{~mm}$ greater than the baseline condition.

Increases of $36 \%, 33 \%$, and $17 \%$ are projected to occur for the month of June for the Mullen site under the A2, $\mathrm{A} 1 \mathrm{~B}$, and $\mathrm{B} 1$ climate scenarios relative to the baseline. For the summer months of July, small decreases of $7 \%, 4 \%$, and $4 \%$ are projected for the $\mathrm{A} 2, \mathrm{~A} 1 \mathrm{~B}$, and $\mathrm{B} 1$ scenarios. For September, small decreases of $2 \%, 7 \%$, and $16 \%$ are also projected. At the Harrison site, decreases of $38 \%$ and $43 \%$ are expected to occur during the month of September for the $\mathrm{A} 2$ and $\mathrm{A} 1 \mathrm{~B}$ scenarios, while an increase of $3 \%$ is anticipated for the B1 scenario.

\section{SEDIMENT}

Among the four locations, average annual sediment yields were greatest at the Columbus site and least at the Mullen site for the four respective climate scenarios (table 7). On an average annual percentage basis, the Sioux City site exhibited the greatest percentage increases in

Table 7. Average annual sediment, total nitrogen and total phosphorus the four test sites under the baseline and three future climate scenarios.

\begin{tabular}{|c|c|c|c|c|c|c|c|}
\hline \multirow[b]{2}{*}{ Site } & \multirow[b]{2}{*}{$\begin{array}{l}\text { Climate } \\
\text { Scenario }\end{array}$} & \multicolumn{2}{|c|}{ Sediment } & \multicolumn{2}{|c|}{ Total N } & \multicolumn{2}{|c|}{ Total P } \\
\hline & & $\begin{array}{c}\text { Yield } \\
\left(\text { tons ha }^{-1}\right)\end{array}$ & $\begin{array}{c}\text { Change } \\
\text { from Base }\end{array}$ & $\begin{array}{c}\text { Yield } \\
\left(\mathrm{kg} \mathrm{ha}^{-1}\right)\end{array}$ & $\begin{array}{c}\text { Change } \\
\text { from Base }\end{array}$ & $\begin{array}{c}\text { Yield } \\
\left(\mathrm{kg} \mathrm{ha}^{-1}\right)\end{array}$ & $\begin{array}{c}\text { Change } \\
\text { from Base }\end{array}$ \\
\hline \multirow[t]{4}{*}{ Columbus } & Base & 4.67 & - & 17.2 & - & 3.14 & - \\
\hline & A2 & 6.31 & $35 \%$ & 22.6 & $31 \%$ & 4.01 & $28 \%$ \\
\hline & A1B & 5.98 & $28 \%$ & 19.9 & $16 \%$ & 3.63 & $16 \%$ \\
\hline & B1 & 5.65 & $21 \%$ & 18.7 & $9 \%$ & 3.45 & $10 \%$ \\
\hline \multirow[t]{4}{*}{ Sioux City } & Base & 2.03 & - & 9.0 & - & 1.67 & - \\
\hline & A2 & 3.75 & $85 \%$ & 14.4 & $60 \%$ & 2.53 & $52 \%$ \\
\hline & A1B & 3.49 & $72 \%$ & 13.6 & $51 \%$ & 2.40 & $44 \%$ \\
\hline & B1 & 3.45 & $70 \%$ & 14.0 & $56 \%$ & 2.45 & $47 \%$ \\
\hline \multirow[t]{4}{*}{ Mullen } & Base & 1.24 & - & 15.8 & - & 0.68 & - \\
\hline & A2 & 1.26 & $2 \%$ & 14.2 & $-10 \%$ & 0.55 & $-19 \%$ \\
\hline & A1B & 1.29 & $4 \%$ & 13.6 & $-14 \%$ & 0.54 & $-21 \%$ \\
\hline & B1 & 1.53 & $23 \%$ & 16.6 & $5 \%$ & 0.67 & $-1 \%$ \\
\hline \multirow[t]{4}{*}{ Harrison } & Base & 1.94 & - & 8.4 & - & 1.50 & - \\
\hline & A2 & 1.81 & $-7 \%$ & 5.8 & $-31 \%$ & 0.95 & $-37 \%$ \\
\hline & A1B & 1.52 & $-22 \%$ & 5.0 & $-40 \%$ & 0.81 & $-46 \%$ \\
\hline & B1 & 2.04 & $5 \%$ & 6.5 & $-23 \%$ & 1.10 & $-27 \%$ \\
\hline
\end{tabular}




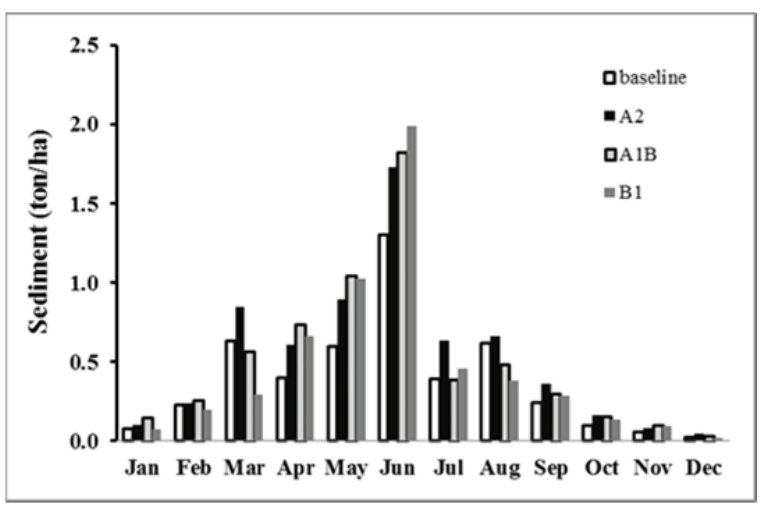

Columbus

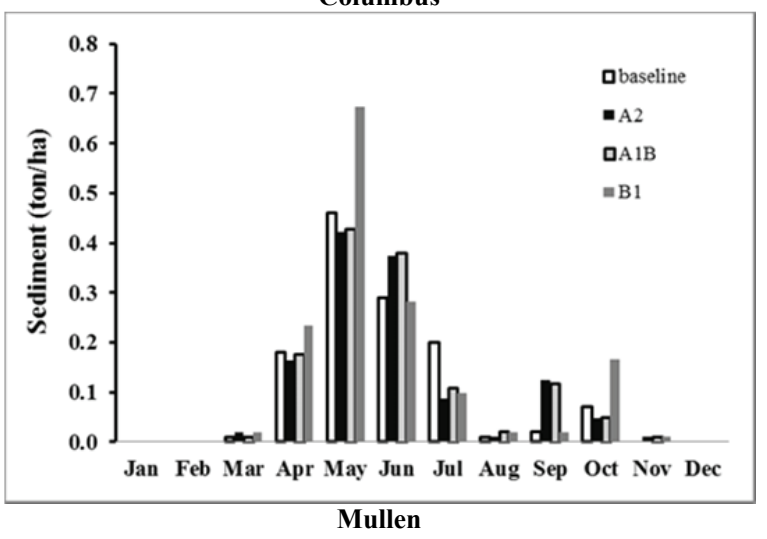

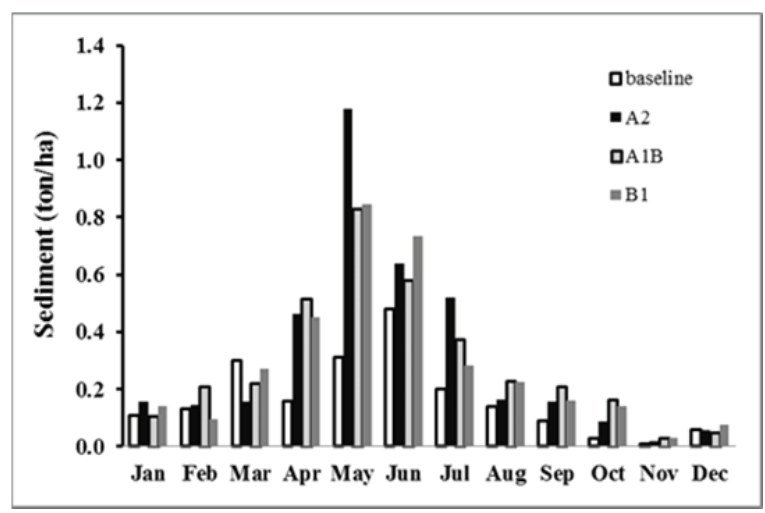

Sioux City

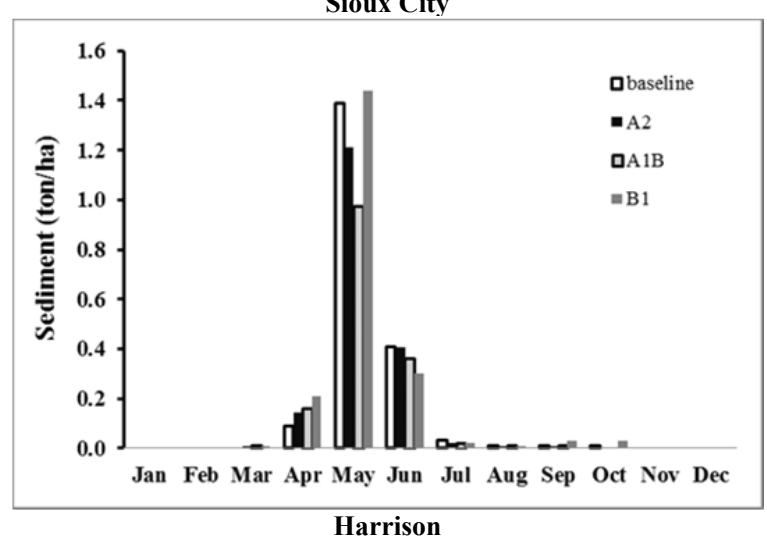

Figure 5. Monthly variations in sediment yield at the four sites under the baseline and three future climate scenarios.

sediment yield, equal to $85 \%, 72 \%$, and $70 \%$ for the $\mathrm{A} 2$, $\mathrm{A} 1 \mathrm{~B}$, and $\mathrm{B} 1$ scenarios compared to the baseline, while respective increases of $35 \%, 28 \%$, and $21 \%$ were simulated at the Columbus site.

Monthly variations in sediment yield for the four sites are illustrated in figure 5 and reflect very different responses for each site. For the Columbus site, sediment yield was greatest during June, with expected percentage increases during that month of $33 \%, 40 \%$, and $53 \%$ for the $\mathrm{A} 2, \mathrm{~A} 1 \mathrm{~B}$, and B1 scenarios relative to the baseline. For the other three sites, sediment yield was highest in May. For that month, huge percentage increases of $280 \%, 167 \%$, and $173 \%$ are projected at the Sioux City site for the A2, A1B, and $\mathrm{B}$ scenarios, respectively, in comparison to the baseline. Most May months simulated at Sioux City for each of the three future climate scenarios exhibited sediment yields that were greater than the May yields simulated for the baseline condition.

\section{NUTRIENTS}

Average annual total $\mathrm{N}$ and total $\mathrm{P}$ for the four sites are reported in table 7 , and monthly nutrient losses for the sites are shown in figures 6 and 7, respectively. For the most part, the model simulations indicated that monthly total phosphorus yields closely follow sediment yields at a particular site. For the two eastern sites, total $\mathrm{N}$ losses were primarily in the organic $\mathrm{N}$ form. At the Harrison site, about one-third of the total $\mathrm{N}$ losses occurred in lateral flow as nitrate; at the Mullen site, about $85 \%$ of the total $\mathrm{N}$ losses occurred in lateral and groundwater flow as nitrate.
For the months of April, May, October, and November, substantial percentage increases in total $\mathrm{N}$ and total $\mathrm{P}$ are projected to occur under the $\mathrm{A} 2, \mathrm{~A} 1 \mathrm{~B}$, and $\mathrm{B} 1$ scenarios relative to the baseline for the Sioux City site. For the month of May, these percentage increases at the Sioux City site amount to $228 \%, 133 \%$, and $148 \%$ for total $\mathrm{N}$ and $218 \%, 134 \%$, and $135 \%$ for total $\mathrm{P}$ under the $\mathrm{A} 2, \mathrm{~A} 1 \mathrm{~B}$, and $\mathrm{B} 1$ scenarios. Decreases in both total $\mathrm{N}$ and total $\mathrm{P}$ are anticipated for the month of May at the Harrison site for each of the three future climate scenarios. These decreases are projected to be $36 \%, 48 \%$, and $24 \%$ for total $\mathrm{N}$ under the A2, A1B, and B1 scenarios compared to the baseline, and $40 \%, 51 \%$, and $30 \%$ for total $\mathrm{P}$, respectively.

\section{FIELD RESPONSE WITH BEST MANAGEMENT PRACTICE IMPLEMENTATION}

The impact of four BMP treatments on changes in sediment, total $\mathrm{N}$, and total $\mathrm{P}$ was compared under the baseline and future climate change scenarios for each site. These four treatments included conversion of the cornsoybean rotation to pasture, switchgrass, and no-till, and implementation of a $10 \mathrm{~m}$ wide edge-of-field buffer strip. Simulations of the impact of the $10 \mathrm{~m}$ buffer strip in SWAT were based on the revised method proposed by White and Arnold (2010). Comparisons of changes in sediment among the BMPs relative to the corn-soybean baseline are presented in figure 8 . Test results show that, with the exception of the $10 \mathrm{~m}$ buffer strip, the impact of implementing a particular BMP on sediment did not vary appreciably between the baseline and any of the future 

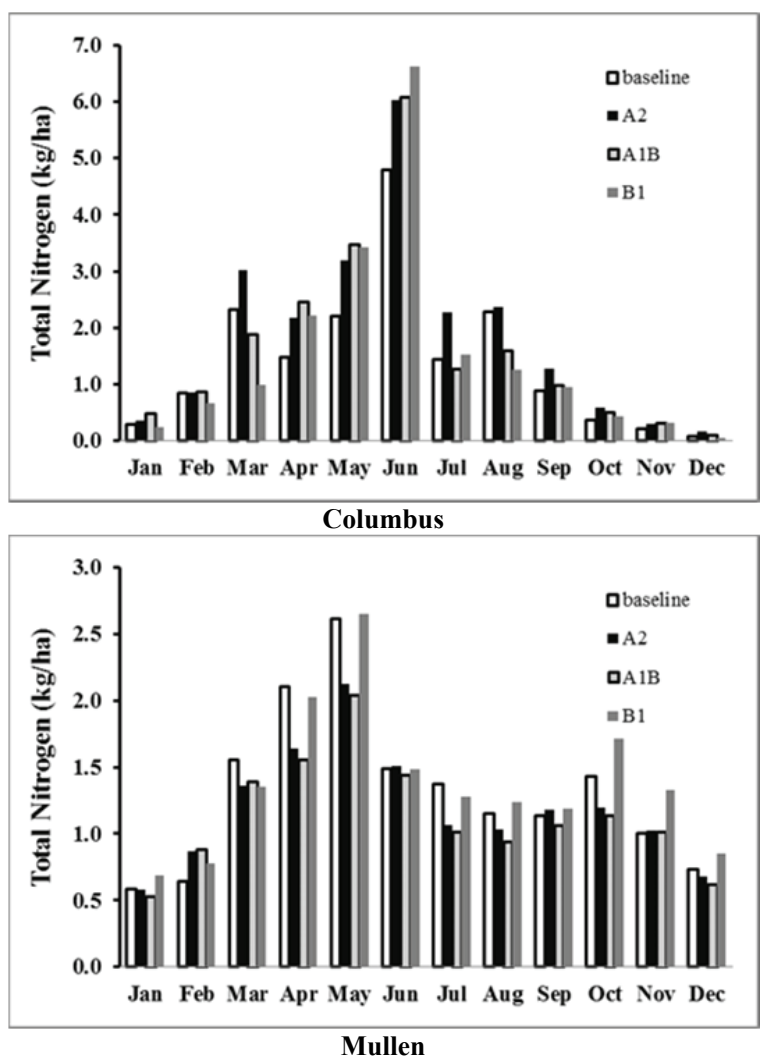
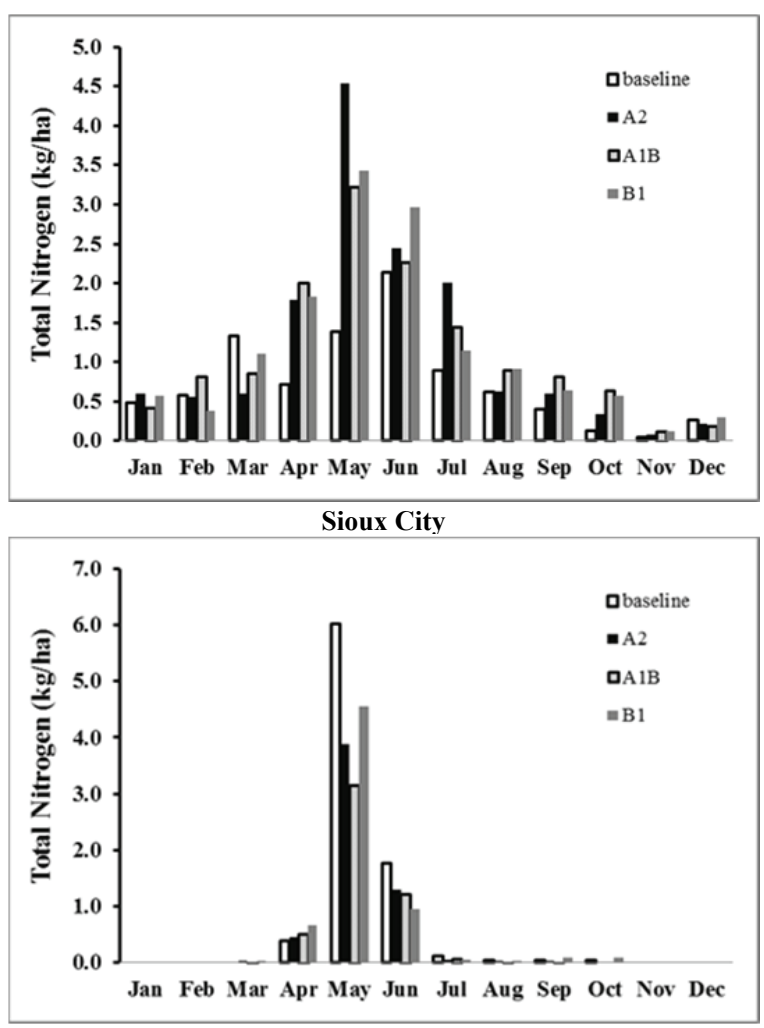

Harrison

Figure 6. Monthly variations in total nitrogen at the four sites under the baseline and three future climate scenarios.
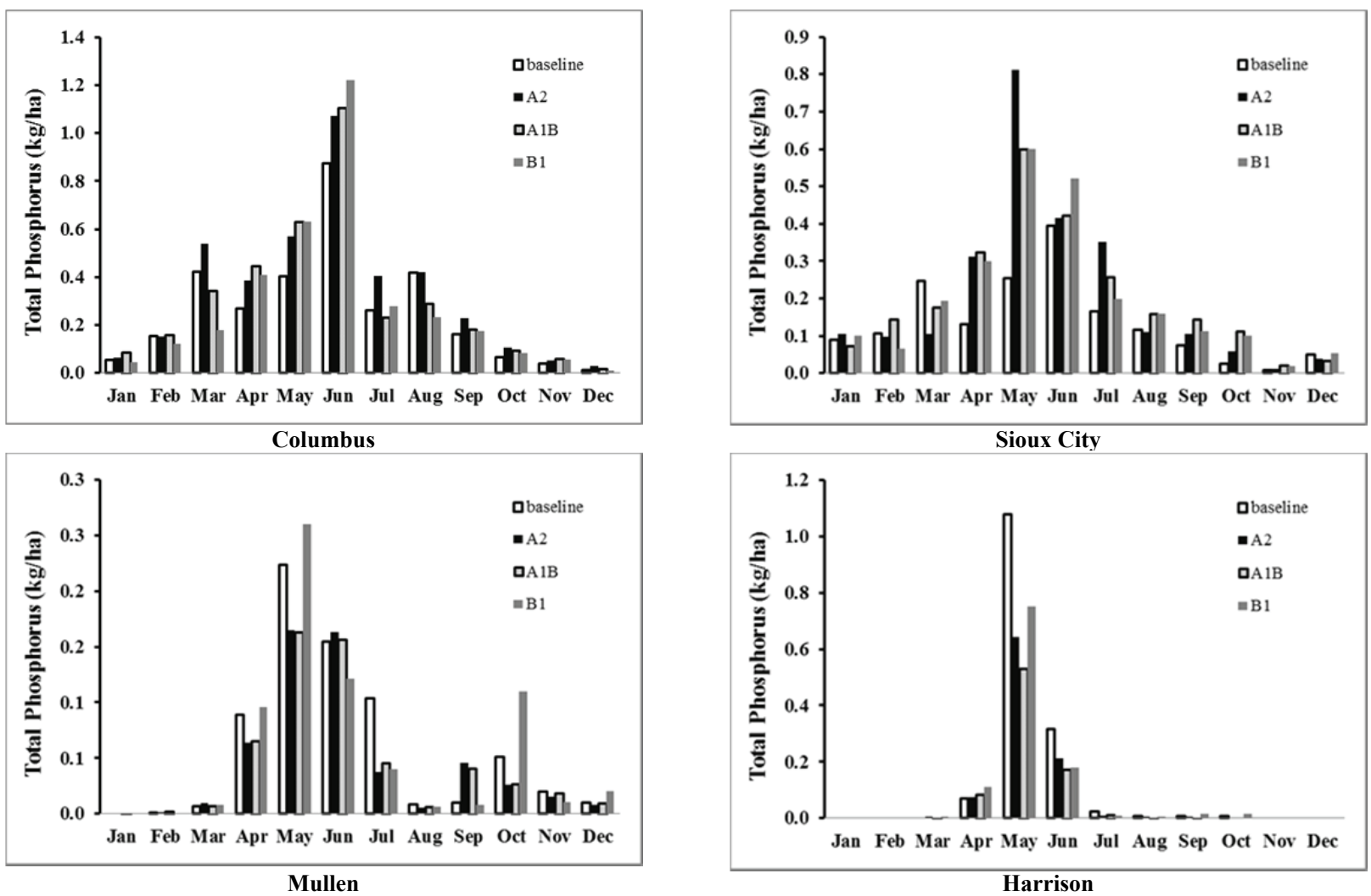

Figure 7. Monthly variations in total phosphorus at the four sites under the baseline and three future climate scenarios. 

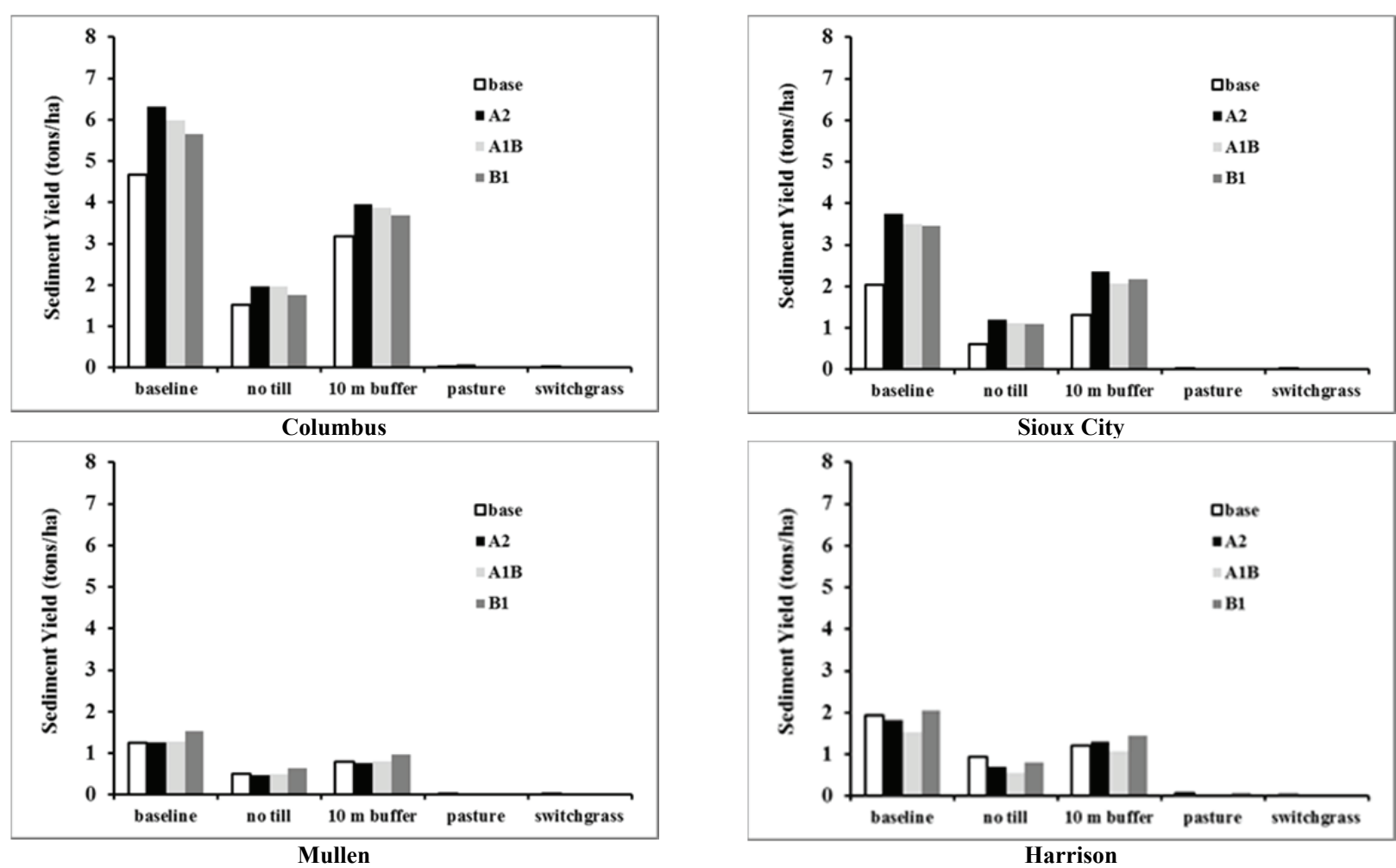

Figure 8. Impact of BMP treatments on average annual sediment for the four field sites under the baseline and three future climate scenarios.

climate scenarios for a given location. At all four sites, the pasture and switchgrass BMPs reduced sediment yield by $97 \%$ to $99 \%$ in comparison to the corn-soybean cover crop. These simulations compare well with those reported by Saxton et al. (1971) and Yuan et al. (2008) for conversion of cropland to grass and Lee et al. (2003) for conversion to switchgrass. No-till treatments were somewhat less effective on the two western sites (52\% to $63 \%$ reductions) in comparison to the two eastern sites $(68 \%$ to $70 \%$ reductions). These reductions are somewhat higher than the $40 \%$ reductions in sediment that Tuppad et al. (2009) simulated using APEX.

Percent reductions in sediment as a result of the $10 \mathrm{~m}$ buffer were slightly greater for the Columbus, Sioux City, and Mullen sites under the three future climate change scenarios in comparison to the baseline condition. At the Sioux City site, for example, percent reductions in sediment were $35 \%, 41 \%, 41 \%$, and $37 \%$ for the baseline, A2, A1B, and B1 scenarios, respectively. Just the opposite was true at the Harrison site, where percent reductions were 38\%, $29 \%, 27 \%$, and $29 \%$ for the baseline, A2, A1B, and B1 scenarios. Because filter strip efficiencies for reducing sediment range from $24 \%$ to $100 \%$ as reported in the literature (White and Arnold, 2010), no attempt was made to compare the results of this investigation with other studies.

For all four sites, the pasture BMP was highly effective in reducing total $\mathrm{N}$ yields (fig. 9) under each of the respective climatic conditions, with reductions ranging from $95 \%$ to $98 \%$. These results compare favorably with total $\mathrm{N}$ losses reported by Schuman et al. (1973) for a pasture watershed in southwest Iowa. For the Columbus and Sioux City sites, the switchgrass BMP yielded results that were similar to the pasture BMP. However, this BMP was less effective for the two western sites, where reductions in total $\mathrm{N}$ ranged from about $59 \%$ to $79 \%$ at Mullen and from $65 \%$ to $88 \%$ at Harrison. The SWAT simulations showed that nitrate was the primary form of nitrogen loss for the switchgrass BMP at the Mullen site, which occurred as nearly equal amounts in lateral and groundwater flow. At the Harrison site, nitrate losses were almost entirely attributed to lateral flow. Under the no-till BMP treatment, reductions in total $\mathrm{N}$ ranged from about $52 \%$ to $59 \%$ for the two eastern sites. These reductions are less than the $69 \%$ reduction reported by Laflen and Tabatabai (1984), who conducted field experiments under simulated rainfall in western Iowa, but greater than the $29 \%$ reduction for total $\mathrm{N}$ reported by Tuppad et al. (2009). Total $\mathrm{N}$ reductions for the no-till BMP ranged from $37 \%$ to $40 \%$ for the Harrison site; no reductions were realized at the Mullen site. This was attributed to the fact that nearly all of the $\mathrm{N}$ losses in the form of nitrate were transported as either lateral or groundwater flow from this site. For the $10 \mathrm{~m}$ buffer BMP treatment, reductions in total $\mathrm{N}$ ranged from $22 \%$ to $27 \%$ for the Columbus and Sioux City sites, and from $22 \%$ (baseline climate scenario) to $15 \%$ (all future climate scenarios) at the Harrison site. The $10 \mathrm{~m}$ buffer was far less effective in reducing total $\mathrm{N}$ losses at the Mullen site, where reductions ranged from $3 \%$ to $5 \%$.

Figure 10 shows that total $\mathrm{P}$ reductions due to BMP implementation closely followed the sediment reductions simulated for each of the four sites. For the most part, there was no appreciable variation between the baseline and any of the future climate scenarios in terms of total $\mathrm{P}$ reductions for a particular BMP. At all four sites, the pasture and switchgrass BMPs were highly effective in reducing total $\mathrm{P}$ 

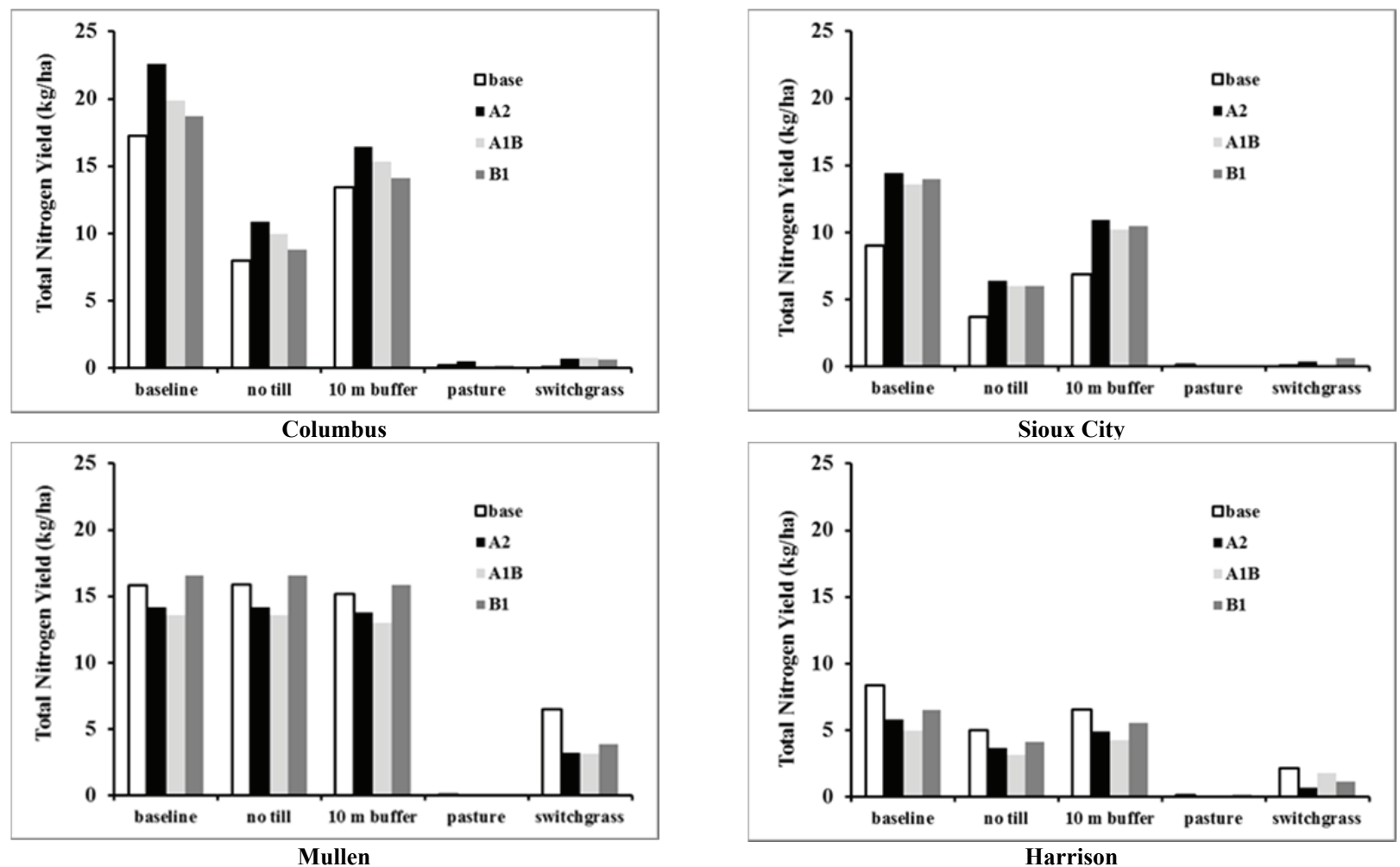

Figure 9. Impact of BMP treatments on average annual total $N$ for the four field sites under the baseline and three future climate scenarios.
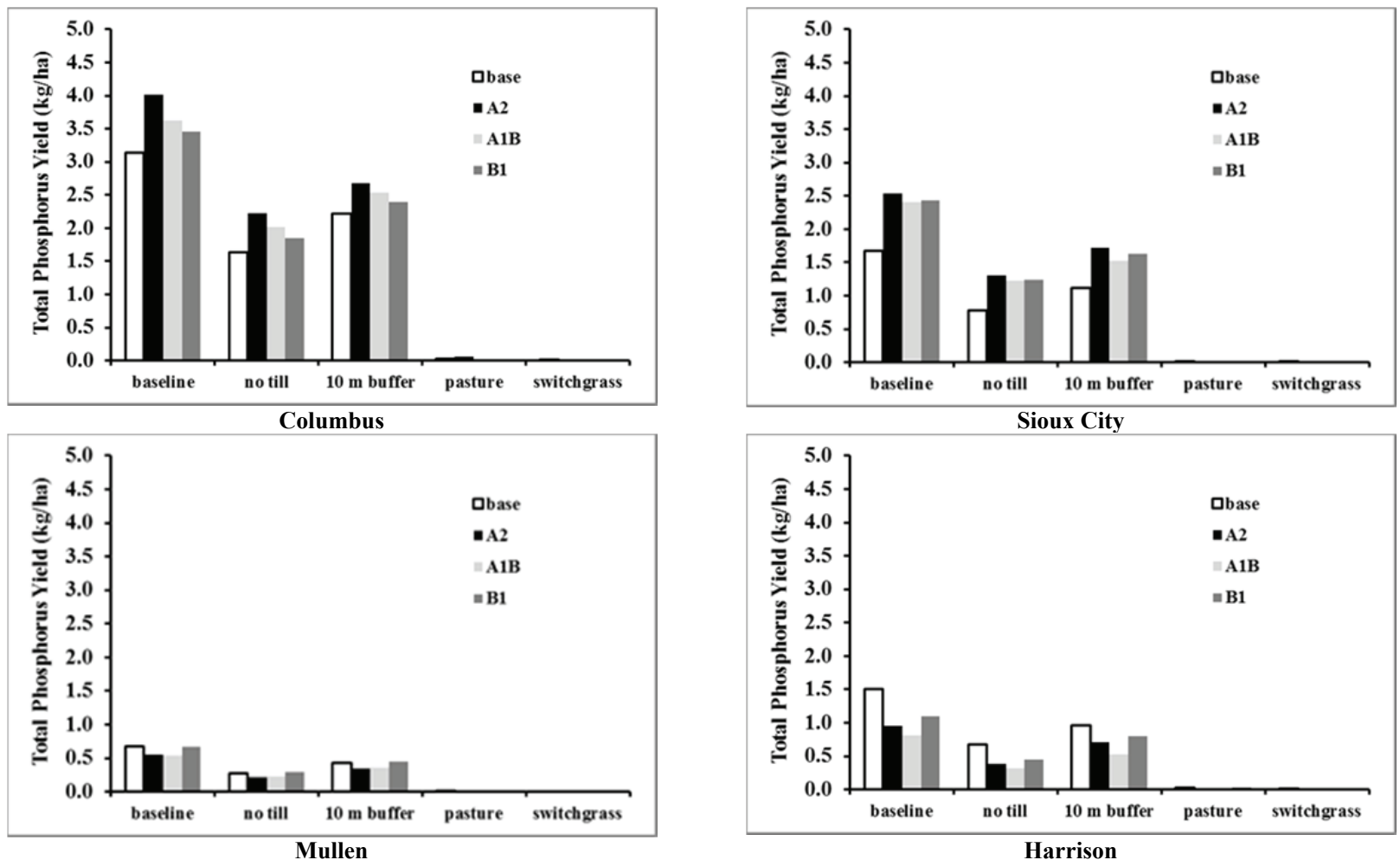

Figure 10. Impact of BMP treatments on average annual total $P$ for the four field sites under the baseline and three future climate scenarios.

yields. Total P reductions for the no-till BMP ranged from $43 \%$ to $53 \%$ at the Columbus and Sioux City sites and from $55 \%$ to $60 \%$ at the Mullen and Harrison sites. These reductions from all four sites fall within the lower and upper values of $21 \%$ and $71 \%$ reported by Tuppad et al.
(2009) and Laflen and Tabatabai (1984), respectively. Similar to the sediment response noted above, reductions in total $\mathrm{P}$ for the $10 \mathrm{~m}$ buffer BMP were not as effective as those for no-till, ranging from about $26 \%$ to $37 \%$ at all four sites. 


\section{DisCUSSION}

The model simulations performed in this study reflect both similarities and differences in runoff, sediment, and nutrient responses that would be expected to occur from the landscape for hypothetical field conditions that were assumed to exist at each of the four field sites. Since topographic and crop cover conditions were identical at each site, the simulated responses are primarily attributed to the integrated effects of climatic, soil, and aquifer conditions. Test results suggest that, in general, higher runoff is anticipated for spring and early summer months under future climatic conditions. As shown in figure 4, these increases are much more pronounced for the two eastern sites than for the two western sites. Wetter springs expected for the future will likely lead to greater flooding potential and the need to implement practices on the landscape that can mitigate against these conditions. The model simulations performed in this study also indicate that somewhat lower runoff rates are anticipated during portions of the summer and fall months for three of the four sites: Columbus (August; A1B and B1), Mullen (July and Sept.), and Harrison (Sept. and Oct.; A2 and A1B). At the field scale, dryer conditions could adversely affect the availability of water to meet irrigation requirements. At the watershed scale, lower runoff rates could adversely impact local water supplies, aquatic habitat, and downstream water needs.

Although the Columbus and Sioux City sites are only approximately $140 \mathrm{~km}$ away from each other, noteworthy differences were simulated in both the temporal distribution and the impact of projected future climatic conditions on runoff and pollutant loading. In general, increases in precipitation during certain times of the year projected for future climatic conditions relative to the baseline were greater for the Sioux City site than for the Columbus site. This in turn led to larger increases in runoff and constituent losses for the future climatic conditions in comparison to the baseline. Considerable differences in hydrologic and water quality responses noted between the Mullen and Harrison sites were largely attributed to substantial differences in precipitation amounts and temporal distributions and aquifer properties for these two locations. Average annual runoff from the Mullen site was 2.9, 3.1, 3.4, and 3.0 times that from the Harrison site for the baseline, A2, A1B, and B1 climate scenarios, respectively. For the Mullen site, surface and subsurface runoff contributed about $22 \%$ and $78 \%$ to total runoff, respectively; for the Harrison site, these contributions were about $69 \%$ and $31 \%$, respectively.

The simulations performed in this study reflect considerable variability in hydrologic and water quality responses among the four field sites that are expected to occur under the future climate change scenarios. To determine how these responses vary across Nebraska, the amount of change in precipitation, ET, irrigation water requirement, and runoff expressed as an average of the three future climate scenarios relative to the baseline was tabulated, as shown in figure 11. Average percent changes in runoff, sediment, total $\mathrm{N}$, and total $\mathrm{P}$ are also shown in figure 11. Values displayed in figure 11 reflect anticipated increases or decreases in these seven variables over a longitudinal distance of approximately $650 \mathrm{~km}$. At all four sites, precipitation under the future climate change scenarios is expected to increase from $18 \mathrm{~mm}$ (Harrison) to $42 \mathrm{~mm}$ (Sioux City) relative to the baseline. Simulation results show that ET will decrease about $29 \mathrm{~mm}$ at the two eastern sites but increase by $35 \mathrm{~mm}$ at the Harrison site. Corresponding to these anticipated changes in ET, irrigation water requirements for the corn-soybean rotation simulated at the Sioux City, Columbus, and Mullen sites will be less than those under current conditions. Based on an average of the three climate change scenarios, decreases of about 54,37, and $35 \mathrm{~mm}$, respectively, are projected for these three sites relative to the baseline. An increase of $15 \mathrm{~mm}$ in the average annual water required for irrigation is projected for the Harrison site, based on the average of the three future climate scenarios. However, for the peak irrigation month of July at Harrison, projected water requirements will be much greater: 37,39 , and $32 \mathrm{~mm}$, respectively, for the $\mathrm{A} 2, \mathrm{~A} 1 \mathrm{~B}$, and $\mathrm{B} 1$ scenarios. The differences displayed in future projected water balances among the four sites have important implications regarding water availability and crop water requirements. Preliminary findings suggest that, under future climatic conditions, existing wetter landscapes will exhibit higher runoff rates and lower ET demands. On the other hand, existing dryer landscapes will exhibit lower levels of water availability and greater ET demands, with the potential for adversely affecting agricultural production.

On a percentage basis, sediment showed the widest change across the four sites, while runoff exhibited the smallest change. The percent change relative to the baseline was about the same for each of the nutrients. Large increases in runoff, sediment, total $\mathrm{N}$, and total $\mathrm{P}$ of about $55 \%, 76 \%, 56 \%$, and $48 \%$, respectively, are projected for the Sioux City site and are somewhat less than those reported by Van Liew et al. (2012) at the watershed scale for the Logan Creek watershed in eastern Nebraska. Moderate increases in runoff, sediment, total N, and total P are projected to occur at the Columbus site; these projected increases are similar in magnitude to those reported by Woznicki et al. (2011), who investigated climate change impacts on streamflow and water quality for the Tuttle Creek Lake watershed in southeastern Nebraska and northeastern Kansas. Decreases of about 2\%, 8\%, 31\%, and $37 \%$, respectively, are projected at Harrison, relative to the present-day baseline. At both of the Columbus and Sioux City sites, substantial increases in pollutant loading from the landscape are projected to occur during the months of May and June. These anticipated changes have serious implications for future soil sustainability and water quality impairments of streams, lakes, or other water bodies.

All four of the BMP treatments employed in this study appear to hold promise in providing potential reductions in sediment and nutrients for the two eastern sites. However, further analyses are needed to not only assess the impact of other types of BMPs but their cost-effectiveness and sustainability as well. The model simulations performed in this study suggest that, for the Harrison site, moderate 

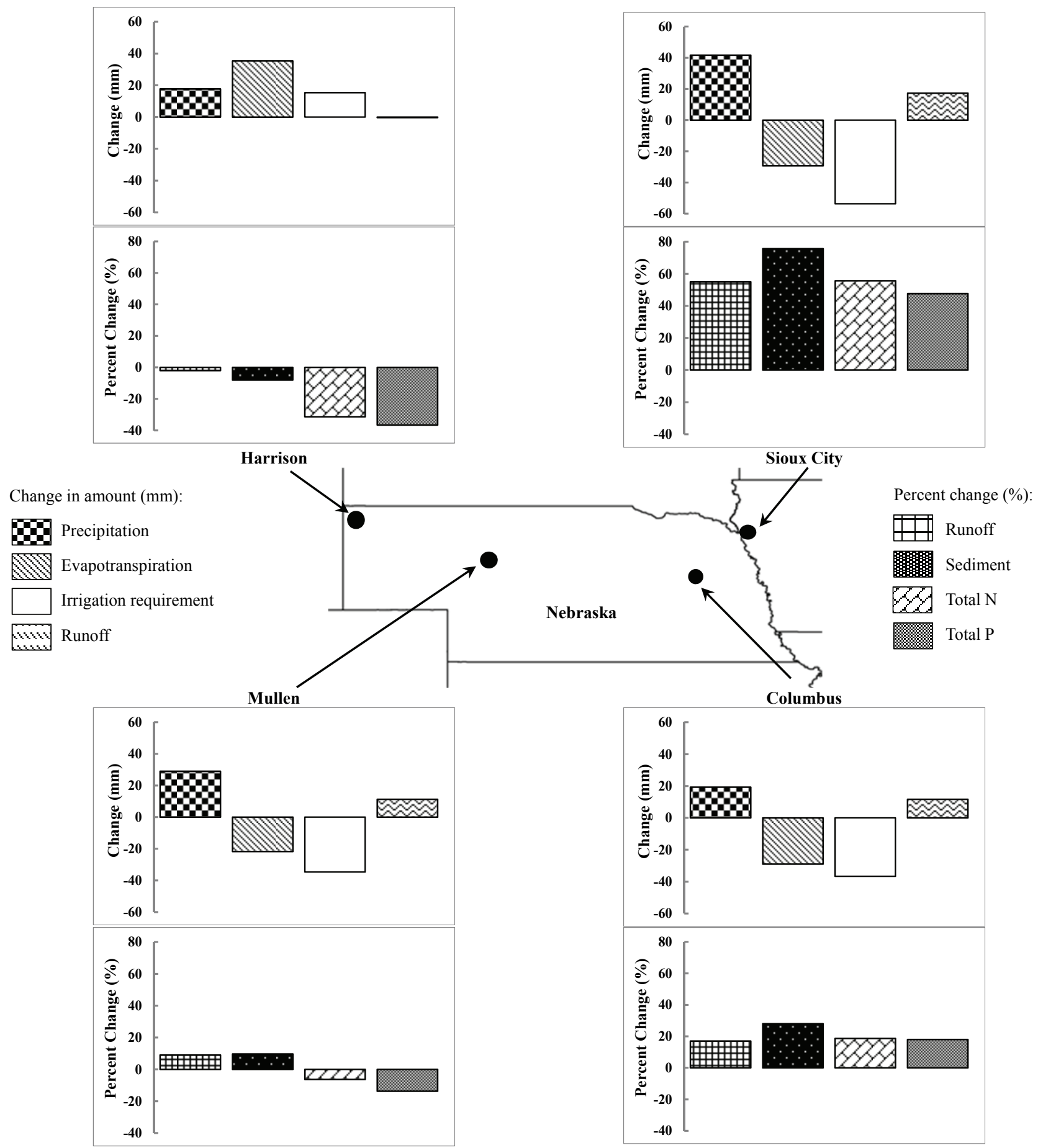

Figure 11. Change in precipitation, ET, irrigation water requirement, and runoff amounts, and percent changes in runoff, sediment, total N, and total $P$ for the four study sites expressed as an average of the three future climate scenarios relative to the present-day baseline.

decreases in sediment, total $\mathrm{N}$, and total $\mathrm{P}$ are projected to occur for the no-till BMP, and substantial decreases for the pasture and switchgrass BMPs. The model simulations also suggest that of the four BMP types, only the pasture and switchgrass treatments appear to provide ample reductions in sediment and nutrients at the Mullen site.

\section{CONCLUSIONS}

In this study, the impacts of future climate change scenarios on water balance, runoff, and water quality at the field scale for four locations in the Heartland region were assessed. A hypothetical field-scale modeling investigation was conducted using the Soil and Water Assessment Tool 
(SWAT) for simulating hydrologic and water quality responses from agricultural landscapes near Sioux City, Iowa, and Columbus, Mullen, and Harrison, Nebraska.

Notable differences in the hydrologic and water quality response from the four sites were apparent from simulations that were performed using a baseline and three future climatic conditions. These differences in responses were attributed to soil, aquifer, and climatic factors that govern water balance and the fate and transport of sediment, nitrogen, and phosphorus. For the Columbus and Sioux City sites, the greatest changes in runoff and water quality were generally projected to occur under the A2 future climate change scenario, followed by the A1B, and B1 scenarios, in comparison to the baseline scenario. For the Mullen site, no one particular future climate scenario appeared to be dominant in terms of impact on the four output variables. In comparison to the baseline, the A1B scenario brought about the largest overall changes in landscape response at the Harrison site, followed by the A2 and B1 scenarios.

The model simulations indicated that for the two eastern sites, where current average annual precipitation is greater than $650 \mathrm{~mm}$, substantial increases in runoff and pollutant loadings from the landscape are projected to occur during the spring under future climate scenarios, in comparison to existing conditions. Considerably greater efforts are therefore anticipated for the future in the implementation of BMPs and adaptation strategies that can be employed to conserve soil and water resources and to protect streams and receiving waters from the harmful effects of higher pollutant loadings. For the Harrison site, where average annual precipitation is less than $450 \mathrm{~mm}$, increases in ET and crop water requirements for irrigation were projected to occur under future climate change scenarios. For regions in western Nebraska with similar or lesser precipitation levels, these anticipated changes could exacerbate existing challenges for agricultural producers who rely heavily upon irrigation water.

Changes in air temperature, precipitation, $\mathrm{CO}_{2}$, and leaf area index under future climatic conditions suggest that these variables will impact water balances in various ways that are not easily defined. Although detailed studies are needed to better understand the role of these and other climate and plant variables on hydrologic processes, the findings from this study accentuate the need for defining these cause-and-effect relationships at relatively fine scales. In light of the considerable differences in the spatial and temporal variations in climatic conditions expected for the future, the results of this study highlight the importance of prescribing measures and implementing practices that are effective in conserving soil and water resources and minimizing pollutant losses at scales such as HUC 8 or finer.

The findings of this study demonstrate that SWAT can be used at the field scale to assess the impact of existing and future climate scenarios on runoff and water quality and to assess the impact of BMP treatments on pollutant load reductions. SWAT therefore holds promise as a planning tool to assist agricultural producers in adapting management strategies that are best suited for conserving water, soil, and nutrient resources under projected changes in future climate. Because this pilot study was performed on only four locations in the Heartland region, additional studies with different climate, crop, management, and soil conditions are needed to assess runoff and water quality responses throughout the region.

\section{ACKNOWLEDGEMENT} 1179.

Song Feng is partly supported by multi-state project NC

\section{REFERENCES}

Arnold, J. G., R. Srinivasan, R. S. Muttiah, and J. R. Williams. 1998. Large-area hydrologic modeling and assessment: Part I. Model development. J. American Water Resources Assoc. 34(1): 73-89.

Donner, S. D., M. T. Coe, J. D. Lenters, T. E. Twine, and J. A. Foley. 2002. Modeling the impact of hydrological changes on nitrate transport in the Mississippi River basin from 1955 to 1994. Global Biogeochem. Cycles 16(3): doi: 10.1029/2001GB001396.

Eckhardt, K., and U. Ulbrich. 2003. Potential impacts of climate change on groundwater recharge and streamflow in a central European low mountain range. J. Hydrol. 284(1-4): 244-252.

Feng, S., C. H. Ho, Q. Hu, R. J. Oglesby, S. J. Jeong, and B. M. Kim. 2011. Evaluating observed and projected future climate changes using the Köppen-Trewartha climate classification. Climate Dynamics 38(7-8): 1359-1373.

Ficklin, D. L., Y. Z. Luo, E. Luedeling, and M. H. Zhang. 2009. Climate change sensitivity assessment of a highly agricultural watershed using SWAT. J. Hydrol. 374(1-2): 16-29.

Field, C. B., R. B. Jackson, and H. A. Mooney. 1995. Stomatal responses to increased $\mathrm{CO}_{2}$ : Implications from the plant to the global scale. Plant Cell Environ. 18(10): 1214-1225.

Githui, F., W. Gitau, F. Mutua, and W. Bauwens. 2009. Climate change impact on SWAT-simulated streamflow in western Kenya. Intl. J. Climatol. 29(12): 1823-1834.

Goolsby, D. A., W. A. Battaglin, and G. B. Lawrence. 1999. Flux and sources of nutrients in the Mississippi-Atchafalaya River basin: Topic 3 report for the Integrated Assessment on Hypoxia in the Gulf of Mexico. Decision Analysis Series No. 17. Silver Spring, Md.: NOAA Coastal Ocean Program.

Hanratty, M. P., and H. G. Stefan. 1998. Simulating climate change effects in a Minnesota agricultural watershed. J. Environ. Qual. 27(6): 1524-1532.

Jha, M., Z. Pan, E. S. Takle, and R. Gu. 2004. Impacts of climate change on streamflow in the Upper Mississippi River basin: A regional climate model perspective. J. Geophys. Research 109(D9): D09105, doi: 10.1029/2003JD003686.

Joos, F., I. C. Prentice, S. Sitch, R. Meyer, G. Hooss, G.-K. Plattner, S. Gerber, and K. Hasselmann. 2001. Global warming feedbacks on terrestrial carbon uptake under the Intergovernmental Panel on Climate Change (IPCC) emission scenarios. Global Biogeochem. Cycles 15(4): 891-907.

Karl, T. R., J. M. Melillo, and T. C. Peterson. 2009. Global Climate Change Impacts in the United States. New York, N.Y.: Cambridge University Press.

Laflen, J. M., and M. A. Tabatabai. 1984. Nitrogen and phosphorus losses from corn-soybean rotations as affected by tillage practices. Trans. ASAE 27(1): 58-63.

Lee, K. H., I. M. Isenhart, and R. C. Schultz. 2003. Sediment and nutrient removal in an established multi-species riparian buffer. J. Soil and Water Cons. 58(1): 1-8.

Lioubimtseva, E., R. Cole, J. M. Adams, and G. Kapustin. 2005. 
Impacts of climate and land-cover changes in arid lands of central Asia. J. Arid Environ. 62(2): 285-308.

Maurer, E. P., J. C. Adam, and A. W. Wood. 2009. Climate model based consensus on the hydrologic impacts of climate change to the Rio Lempa basin of Central America. Hydrol. and Earth System Sci. 13(2): 183-194.

Meehl, G. A., C. Covey, T. Delworth, M. Latif, B. McAvaney, J. F. B. Mitchell, R. J. Stouffer, and K. E. Taylor. 2007. The WCRP CMIP3 multi-model dataset: A new era in climate change research. Bull. American Meteorol. Soc. 88(9): 1383-1394.

Monteith, J. L. 1965. Evaporation and the environment. In Proc. XIXth Symp. Soc. for Exp. Biol.: The State and Movement of Water in Living Organisms, 205-234. Cambridge, U.K.: Cambridge University Press.

Moriasi, D. N., J. G. Arnold, M. W. Van Liew, R. L. Bingner, R. D. Harmel, and T. L. Veith. 2007. Model evaluation guidelines for systematic quantification of accuracy in watershed simulations. Trans. ASABE 50(3): 885-900.

Morison, J. I. L. 1987. Intercellular $\mathrm{CO}_{2}$ concentration and stomatal response to $\mathrm{CO}_{2}$. In Stomatal Function, 229-251. E. Zeiger, I. R. Cowan, and G. D. Farquhar, eds. Palo Alto, Cal.: Stanford University Press.

Nakićenović, N., and R. Swart. 2000. Special report on emission scenarios. Special report of Working Group III of the Intergovernmental Panel on Climate Change. Cambridge, U.K.: Cambridge University Press.

Nash, J. E., and J. W. Sutcliffe. 1970. River flow forecasting though conceptual models: Part I. A discussion of principles. J. Hydrol. 10(3): 282-290.

Neitsch, S. L., J. G. Arnold, J. A. Kiniry, R. Srinivasan, and J. R. Williams. 2002. Soil and Water Assessment Tool User's Manual: Version 2000. GSWRL Report 02-02, BRC Report 02-06. College Station, Tex.: Texas Water Resources Institute.

Pierce, D. W., T. P. Barnett, B. D. Santer, and P. J Gleckler. 2009. Selecting global climate models for regional climate change studies. Proc. Natl. Acad. Sci. 106(21): 8441-8446.

Pritchard, S. G., H. H. Rogers, S. A. Prior, and C. M. Peterson. 1999. Elevated $\mathrm{CO}_{2}$ and plant structure: A review. Global Change Biol. 5(7): 807-837.

Reichler, T., and J. Kim. 2008. How well do coupled models simulate today's climate? Bull. American Meteorol. Soc. 89(3): 303-311.

Saxton, K. E., R. G. Spomer, and L. A. Kramer. 1971. Hydrology and erosion of loessial watersheds. J. Hydraul. Div. ASCE 97(11): 1835-1851.

Schilling, K. E., M. K. Jha, Y. K. Zhang, P. W. Gassman, and C. F. Wolter. 2008. Impact of land use and land cover change on the water balance of a large agricultural watershed: Historical effects and future directions. Water Resources Res. 44(7): W00A09, doi: 10.1029/2007WR006644.

Schuman, G. E., R. E. Burwell, R. F. Priest, and R. G. Spomer. 1973. Nitrogen losses in surface runoff from agricultural watersheds on Missouri Valley loess. J. Environ. Qual. 2(2): 299-302.

Semenov, M. A., and P. Stratonovitch. 2010. Use of multi-model ensembles from global climate models for assessment of climate change impacts. Climate Research 41(1): doi: 10.3354/cr00836.

Storm, D. E., P. R. Busteed, and M. J. White. 2006. Fort Cobb basin: Modeling and land cover classification. Stillwater, Okla.:
Oklahoma State University, Department of Biosystems and Agricultural Engineering. Available at: https://www.deq.state. ok.us/WQDnew/tmdl/fort_cobb/osu_fort_cobb_modeling_jan 2006.pdf. Accessed 25 June 2012.

Tollan, A. 2002. Land use change and floods: What do we need most, research or management? Water Sci. and Tech. 45(8): 183190.

Tomer, M. D., and K. E. Schilling. 2009. A simple approach to distinguish land-use and climate-change effects on watershed hydrology. J. Hydrol. 376(1-2): 24-33.

Tuppad, P., M. F. Winchell, X. Wang, R. Srinivasan, and J. R. Williams. 2009. ArcAPEX: ArcGIS interface for Agricultural Policy Environmental Extender (APEX) hydrology/water quality model. Intl. Agric. Eng. J. 18(1-2): 59-71.

Twine, T. E., C. J. Kucharik, and J. A. Foley. 2004. Effects of land cover change on the energy and water balance of the Mississippi River basin. J. Hydrometeorol. 5(4): 640-655.

USDA-SCS. 1986. Urban hydrology for small watersheds Technical Release No. 55 (TR-55). Washington, D.C.: USDA Soil Conservation Service.

Van Liew, M. W., and K. E. Saxton. 1984. Dynamic simulation of sediment discharge from agricultural watersheds. Trans. ASAE 27(4): 1087-1092.

Van Liew, M. W., C. H. Green, and P. J. Starks. 2007. Unit source area data: Can it make a difference in calibrating the hydrologic response for watershed-scale modeling? J. Soil and Water Cons. 62(3): 162-170.

Van Liew, M. W., S. Feng, and T. B. Pathak. 2012. Climate change impacts on streamflow, water quality, and best management practices for the Shell and Logan Creek watersheds in Nebraska. Intl. J. Agric. and Biol. Eng. 5(1): 13-34.

Wand, S. J. E., G. F. Midgley, M. H. Jones, and P. S. Curtis. 1999. Responses of wild $\mathrm{C} 4$ and $\mathrm{C} 3$ grass (Poaceae) species to elevated atmospheric $\mathrm{CO}_{2}$ concentrations: A meta-analytic test of current theories and perceptions. Global Change Biol. 5(6): 723-741.

Weiss, A., C. J. Hays, and J. Won. 2003. Assessing winter wheat responses to climate change scenarios: A simulation study in the U.S. Great Plains. Climate Change 58(1-2): 119-147.

White, M. J., and J. G. Arnold. 2010. Development of a simplistic vegetative filter strip model for sediment and nutrient retention at the field scale. Hydrol. Proc. 23(11): 1602-1616.

White, M. J., D. E. Storm, P. R. Busteed, M. D. Smolen, H. Zhang, and G. A. Fox. 2010. A quantitative phosphorus loss assessment tool for agricultural fields. Environ. Model. and Software 25(10): 1121-1129.

Wilby, R. L., H. G. Orr, M. Hedger, D. Forrow, and M. Blackmore. 2006. Risks posed by climate change to the delivery of water framework directive objectives in the U.K. Environ. Intl. 32(8): 1043-1055.

Williams, J. R. 1975. Sediment routing for agricultural watersheds. Water Resources Bull. 11(5): 965-974.

Woznicki, S. A., A. P. Nejadhashemi, and C. M. Smith. 2011. Assessing best management practice implementation strategies under climate change scenarios. Trans. ASABE 54(1): 171-190.

Yuan, Y., M. A. Locke, and R. L Bingner. 2008. Annualized agricultural nonpoint-source model application for Mississippi Delta Beasley Lake watershed conservation practices assessment. J. Soil and Water Cons. 63(6): 542-551. 